\title{
Enablers to Implement Sustainable Initiatives in Agri-food Supply Chains
}

\author{
Sachin Kumar Mangla \\ Lecturer in Knowledge Management and Business Decision Making \\ Plymouth Business School (PBS) \\ University of Plymouth, Plymouth, PL4 8AA, United Kingdom \\ E-mail: sachinmangl@gmail.com \\ sachin.kumar@plymouth.ac.uk \\ Sunil Luthra \\ Department of Mechanical Engineering,
}

State Institute of Engineering and Technology (Formerly known as Government Engineering College),

Nilokheri-132117, Haryana, India

E-mail: sunilluthra1977@gmail.com

\author{
Nick Rich* \\ School of Management, \\ Fabian Way, Swansea, Wales, UK \\ E-mail: N.L.Rich@swansea.ac.uk \\ Divesh Kumar \\ Department of Management Studies \\ Malviya National Institute of Technology, Jaipur, India \\ Email:diveshcms@gmail.com \\ Nripendra P. Rana \\ School of Management, \\ Fabian Way, Swansea, Wales, UK \\ E-mail: n.p.rana@swansea.ac.uk \\ Yogesh K. Dwivedi \\ School of Management, \\ Fabian Way, Swansea, Wales, UK \\ E-mail: y.k.dwivedi@swansea.ac.uk
}

*Corresponding author 


\title{
Enablers to Implement Sustainable Initiatives in Agri-food Supply Chains
}

\begin{abstract}
Due to rapid industrialization of agriculture, increased global food demand, and, increasing concerns related to food quality and safety, the concept of sustainability and supply chain transparency are becoming critically important to the agriculture and agri-food sector. The addition of sustainability performance objectives not only focuses on the effective utilization and consumption of natural resources, but also drives efforts to balance ecological, economic and societal aspects of agri-food businesses. The management of sustainability adds a new demand on business managers who often have small profits and receive stringent requirements from large powerful customers and retailers. In this paper, we recognize and analyze the key enablers in implementing sustainable initiatives for Agri-Food Supply Chains (A-FSCs). Ten important sustainability driven enablers were considered from a rigorous literature review and phase of expert consultation. The identified enablers were then analyzed using a combined Interpretive Structural Modeling (ISM) - fuzzy Decision Making Trial and Evaluation Laboratory (DEMATEL) based framework. The ISM approach enabled an appreciation of the contextual relationships among the enablers and to classify the enablers based on their driving and dependence potential. The fuzzy DEMATEL technique supported the determination of the influential and influenced enablers and also to categorize them into cause and effect groups. An empirical case study, drawn from a vegetable and fruit retail supply chain in India, is used to focus and test the applicability of the proposed research framework. The paper facilitates professional management practice and researchers to uncover and explore the enablers for the real execution of sustainability oriented initiatives in the agri-food business sector.
\end{abstract}

Keywords: Agri-Food Supply Chain, Sustainable Initiatives, Enablers, ISM-MICMAC, Fuzzy DEMATEL, India

\section{Introduction}

A remarkable increase in food standards requirements, rapid industrialization of agricultural based products and establishment of customer and governmental food safety concerns have resulted in the agri-food and agriculture based products supply chain networks becoming more 
complex (Chen, 2006; Lowe et al., 2008; Svensson and Wagner, 2012). These complex agri-food supply chains (A-FSCs) environment have heightened concerns between nations, such as food safety scares and the unsustainable depletion of natural resources etc. (Food Ethics Council, 2004; Sharma, 2011). From the A-FSCs perspective, agriculture is a significant national resource and large employer. Thus, a systems perspective must be undertaken to appreciate the complexities and holistic properties of each (and the interconnected) value chains both vertically - such as farming, wholesaling, warehousing, processing, and retailing (Dev et al., 2014) - as well as lateral activities where common organizations support multiple value chains. Appropriate implementation of improvement activities may lead to an increase in efficiency and have a continuous improvement in overall performance of A-FSC, organizations. The improvement to the economic benefits, societal considerations, competitive advantages, ecological impacts, are therefore significant for national prosperity (Fritz and Schiefer, 2008; Fischer et al., 2010; Kumar et al., 2013). In addition, increased globalization and growing world population have a huge impact on the sustainability of supply chains, especially within the food industry. The processes in the food value chains are generally characterized by mass production and involve interlinked marketing, procurement, and distribution activities of international standards. The way food is produced, processed, transported, and consumed has a great impact on sustainability throughout the supply chain. Such food value chains aims to deliver an objective of higher customer satisfaction with marginal food wastage (Beske et al., 2014). In food industry, higher product quality and efficient value chain design are considered as very important concerns for any nation's economy (Bourlakis and Weightman, 2008; Zanoni and Zavanella, 2012; Ting et al., 2014; Govindan, 2018). Due to the complexity that persists in coordinating the members of food supply chain, food wastage has increased significantly (Govindan, 2018). There is an increasing consciousness in society that the waste of perishable foods involves a loss of huge natural resources and should be avoided (Li et al., 2014; Sgarbossa and Russo, 2017). In addition, food security and safety are also very crucial issues in developing economies (Gustavsson, et al., 2015). To develop a sustainable agro value chain has been constantly a global challenge in the industry. It is estimated that million people in India are being "fed with grain by over-pumping" of water. India is the second largest food producer country in the world. Agri-food sector contributes 35\% in the GDP and almost two-thirds of the population in India is connected with agriculture for their source of income. However, in a developing economy like India, the wastage 
of grain due to the improper management of food supply chain alone is worth $\$ 1$ billion annually (Grant Thornton, 2014; Anupam, 2017). Every aspect of the economy, polity, and majority of its population are governed by the performance of the agricultural sector (Somashekhar et al., 2014). Poor management of supply chain functions and limited integration of innovations (process and technological) in business are the major contributors to this wastage (Balaji and Arshinder, 2016). In addition to this, food value chains also have to deal with several other challenges, such as climate change, consumer pattern, oil reliance, fair trade and localism, social and environmental concerns, etc ( $\mathrm{Li}$ et al., 2014; Grimm et al., 2014). In order to meet the requirements of healthy and safe food, managers and policy makers need to develop highly sustainable food value chains (Lundqvist, et al., 2008; Zanoni and Zavanella, 2012; Sgarbossa and Russo, 2017). To deal with these global issues, the concept of "sustainability" has an impact on the agriculture and agro or agri-food sector (from here onwards the words agro and agri will be used interchangeably), as it focuses upon the consumption of resources in a most effective way (WCED, 1987). Several key driving forces/enablers can influence the implementation of sustainability improvement programs for an organization's supply chain views. These include the managerial approach, government policies, awareness of customers etc. (Kumar et al., 2016) and these have significant impact on deployment and adoption in A-FSCs (Glover et al., 2014). In this sense, an academic gap exists in identifying and analyzing these enablers for real execution of sustainability concepts in A-FSCs (Fritz and Schiefer, 2008; Grimm et al., 2014).

Banasik et al. (2017) suggested that various decision support tools are needed to evaluating various factors to redesign an agro-food chain that can optimize decision making at chain level. Identifying and analyzing these facets will support business organizations to evaluate suitable strategies for managing agro-food sector sustainability, translating strategy into improvements in their economic, ecological, and social responsibilities. Understanding the contextual relationships between these enablers will help the manufacturers in effectively utilizing their resources and attaining sustainable initiatives in A-FSCs. A substantial amount of research has been focused on examining factors that are critical in implementing sustainable initiatives in supply chains from various perspectives (Ageron et al., 2012; Grimm et al., 2014; Raut et al., 2017; Luthra et al., 2018). To date, little attention has been devoted to enablers for effective adoption of sustainability initiatives in A-FSCs as a whole (from the system perspective). This research tries to answer the three main questions: 
RQ 1: What are the key enablers to implement the sustainable initiatives in A-FSCs?

RQ 2a: What are the contextual relationships between the recognized enablers in response to sustainable initiatives in A-FSCs?

RQ 2b: What are hierarchical levels of key enablers to execute the sustainable initiatives in AFSCs?

RQ 3: How these key enablers can be organized into cause and effect groups to implement sustainable initiatives in A-FSCs?

A-FSC sustainability focused enablers can be selected through the literature and experts' feedback even though organizations will have their local and contingent priorities/viewpoints on adopting sustainability. In this sense, the researchers selected a portfolio of feasible and commonly cited enablers and subsequently evaluated their impact on improving the effective sustainability of A-FSCs. Hence, this research set an ultimate objective of identifying and analyzing the enablers for their contextual relationships and cause and effect groups to implement sustainable initiatives in A-FSCs. The researchers used a systematic literature review in conjunction with experts' feedback to detect the sustainability focused key enablers. The problem undertaken in this work is of the multi-criteria decision type and thus, a combined Interpretive Structural Modeling (ISM) - fuzzy Decision Making Trial and Evaluation Laboratory (DEMATEL) based approach was designed and used as an appropriate methodology (Mehregan et al., 2014). The impact of this research is a novel insight into a contemporary phenomenon and a combined ISM and fuzzy DEMATEL approach to select and evaluate the sustainability focused enablers in A-FSCs (a methodological contribution). ISM assists in analyzing the contextual relationships between the identified enablers, and establishes hierarchical levels as well as relationships between enablers (Mangla et al., 2013). In addition, fuzzy DEMATEL helps to categorize the identified enablers into cause and effect groups (Luthra et al., 2016a). The fuzzy concepts that are used with DEMATEL capture the human bias and uncertainty in the data.

The applicability of the combined ISM - fuzzy DEMATEL approach was applied to an agriculture based vegetable and fruit retail supply chain case study in India (See Eisenhardt, 1989). The case company has a formal objective to improve its ecological, cost-effective and public performances and to commit to sustainable development initiatives (from the system 
perspective). The case organization was also interested in creating a structural model to uncover the enablers of sustainability implementation in the supply chain.

The remainder of this paper is organized as follows. The review of related literature and proposed sustainability focused key enablers in A-FSCs is discussed in Section 2. Section 3 discusses the research methods. Section 4 describes the proposed framework for this research. The problem definition and an application example of the proposed framework to the case company are presented in Section 5. Results along with the implications to management are discussed in Section 6. Finally, Section 7 provides conclusions, limitations and the scope for future research.

\section{Literature Review}

This section contains the literature on A-FSC and sustainability to identify key enablers to sustainable initiative implementation by A-FSCs.

\subsection{A-FSC and Sustainability}

The term "agri-food" concerns the business of producing food agriculturally and A-FSC consists of all the activities, which are involved in the movement of agricultural food produce from the producers/farmers to customers. The important activities in an A-FSC include raw material supply, manufacturing, postharvest, storage, distribution, services, etc. (Ahumada and Villalobos, 2009; Jaffee and Howard 2010; Kumari et al., 2015). In recent years, the concept of sustainability has gained importance in the agriculture industry as production systems become more dependent and a holistic view of the system and its sustainability needs to be undertaken to optimize the outcome benefits of any improvement (Notarnicola et al., 2012).

Sustainability is a significant issue studied from different perspectives in the literature. One of the widely accepted explanations of "sustainability" is that it meets the needs of the present without compromising the ability of future generations to meet their own needs (WECD, 1987).

Sustainable agriculture food supply chains can be understood as networks that focus on closely cooperating enterprises of a value chain with executive coordination provided to coordinate material flow and to foster close working relationships (Fritz and Schiefer, 2008). There are many issues faced by organizations in cooperating and influencing supply chain partners, specifically in agri supply chain where partners are dependent on each other. Hence 
sustainability outcomes can be improved only with the full participation of each partner and supply chain partners need to help each other to produce more sustainable outputs and progress at a common rate (Kumar and Rahman, 2015). Identifying the enablers to such a holistic transformation process for sustainability in agri value chains would therefore assist the promotion of environmental sustainable development and balanced agri-based products/manufacturing in a meaningful and "ecosystem services" approach (FACCE-JPI, 2011; Syahruddin and Kalchschmidt, 2012; Iakovou et al., 2014; Accorsi et al., 2016).

\subsection{Proposed Enablers for Sustainable Initiatives in A-FSCs}

Some studies of agri supply chain sustainability have focused on organic farming issues and related it with rural development (Pugliese, 2001) yet these studies concern production that is already high on the awareness of organics and sustainability (Bhaskaran et al., 2006). Recently Gimenez and Sierra (2013) studied sustainable supply chain governance and cited two key practices: supplier assessment and collaboration with suppliers, which directly affect the ecological sustainability of the supply chain. Clement et al. (2006) proposed an integration of scientific and technology applications and easy transfer of technology among the stakeholders as one of the enablers for the sustainable agri supply chain. Similarly, usage of information and communication technology (ICT) and sharing real time information among supply chain partners related to climate change has been found as a fundamental enabler of sustainability adoption (Grunfeld and Houghton, 2013; Mohezar and Soosay, 2010).

Notably, for implementing any supply chain strategy, it is important to construct procedures and practices that align with a meaningful sustainability strategy. Consequently, managers developing such a strategy for their supply chain should distinguish the relevant key success measures/variables or say enablers for successful adoption of supply chain strategy (Hartono et al., 2015). In this work, enablers can be understood as the success variables and resources that contribute to the success of the adoption of sustainability in A-FSCs (Business Dictionary, 2016).

Multiple key enablers, related to sustainability adoption in the A-FSC sector, were hypothesized to exist and a systematic literature review was conducted by searching for "Driving Factors +Sustainable Initiatives + Agri Supply Chain"; "Key Factors and Sustainable Initiatives and Agri Supply Chain"; "Enablers and Sustainable Initiatives and Agri Supply Chain"; "Drivers and 
Sustainable Initiatives and Agri Food Supply Chain"; "Drivers/Key Factors/Enablers and Sustainability and Agri Food Supply Chain". In addition to this, expert opinion were also be used for identifying enablers. A total of ten important key enablers to implement sustainable initiatives in A-FSC were identified through the combined utilization of literature and expert inputs (Table 1) and Section 5.1 provides more details on the data collection methodology.

Table 1: Key enablers to implement sustainable initiatives in A-FSC

\begin{tabular}{|c|c|c|}
\hline Enablers & mplied Meaning & References \\
\hline $\begin{array}{lrr}\begin{array}{l}\text { Pressure } \\
\text { governmental, }\end{array} & \begin{array}{r}\text { various } \\
\text { regulating }\end{array} \\
\text { agencies and } & \text { non-government } \\
\text { bodies (E1) } & & \end{array}$ & $\begin{array}{l}\text { Pressure from various agencies like } \\
\text { NGOs, the Media and Civil Society } \\
\text { and Regulatory bodies are crucial in } \\
\text { adopting sustainability }\end{array}$ & $\begin{array}{l}\text { Klassen and Vachon, 2003; } \\
\text { Clemens and Douglus, 2006; } \\
\text { Seuring and Muller, 2008; Vachon } \\
\text { and Klassen, 2008; Zhu et al., } \\
\text { 2008; Beske et al., 2014; Kumar } \\
\text { and Rahman, 2015; Ding et al., } \\
2018\end{array}$ \\
\hline $\begin{array}{l}\text { Incentives and support of } \\
\text { various agencies to undertake } \\
\text { sustainable initiatives (E2) }\end{array}$ & $\begin{array}{l}\text { Expectation of getting support from } \\
\text { various sources in term of money, } \\
\text { technology and infrastructure is } \\
\text { important for implementing } \\
\text { sustainability }\end{array}$ & $\begin{array}{l}\text { Simpson and Power, 2005; Lin, } \\
\text { 2007; Matos and Hall, 2007; Bitzer } \\
\text { et al., 2008; Seuring and Muller, } \\
\text { 2008; Van Bommel, 2011; Beske } \\
\text { et al., } 2014\end{array}$ \\
\hline $\begin{array}{l}\text { Understanding customer and } \\
\text { other stakeholder requirements } \\
\text { (E3) }\end{array}$ & $\begin{array}{l}\text { Consumer demand and supply chain } \\
\text { partners' interest in sustainable } \\
\text { agricultural products is significant }\end{array}$ & $\begin{array}{l}\text { Vachon and Klassen, 2008; Zhu et } \\
\text { al., 2008; Holt and Ghobadian, } \\
\text { 2009; Van Bommel, 2011; Diabat } \\
\text { and Govindan, 2011; Kumar and } \\
\text { Rahman, 2013; Grimm et al., 2014; } \\
\text { Mani and Gunasekaran, } 2018\end{array}$ \\
\hline $\begin{array}{l}\text { tanding the sustainability } \\
\text { re importance and } \\
\text { (E4) }\end{array}$ & $\begin{array}{l}\text { Understanding the importance of } \\
\text { sustainable initiatives in agricultural } \\
\text { products and their benefits in long } \\
\text { run are crucial from the } \\
\text { sustainability adoption }\end{array}$ & $\begin{array}{l}\text { Rao and Holt, 2005; Ellis and } \\
\text { Higgins, 2006; Teuteberg and } \\
\text { Wittstruck, 2010; Akhtar et al., } \\
2016\end{array}$ \\
\hline $\begin{array}{l}\text { int involvement, } \\
\text { l commitment (E5) }\end{array}$ & $\begin{array}{l}\text { Top management involvement, } \\
\text { support and commitment can be } \\
\text { very crucial initiatives to incorporate } \\
\text { sustainability }\end{array}$ & $\begin{array}{l}\text { Zhu and Sarkis, 2004; Ellis and } \\
\text { Higgins, 2006; Closs et al., 2010; } \\
\text { Ageron et al., 2012; Wittstruck and } \\
\text { Teuteberg, 2012; Akhtar et al., } \\
2016\end{array}$ \\
\hline $\begin{array}{l}\text { Resources allocation and } \\
\text { information sharing within and } \\
\text { across the hierarchy (E6) }\end{array}$ & $\begin{array}{l}\text { Sharing of the required key } \\
\text { resources and information on the } \\
\text { sustainability efforts among supply } \\
\text { chain partners are significant in } \\
\text { sustainability adoption }\end{array}$ & $\begin{array}{l}\text { Elkington, 1994; Klassen and } \\
\text { Vachon, 2003; Bitzer et al., 2008; } \\
\text { Lee, 2008; Wu and Pagell, 2011; } \\
\text { Ageron et al., 2012; Grimm et al., } \\
2014\end{array}$ \\
\hline $\begin{array}{l}\text { Joint efforts, planning and } \\
\text { capacity building for delivering } \\
\text { sustainability focused products } \\
\text { (E7) }\end{array}$ & $\begin{array}{l}\text { Joint effort of supply chain } \\
\text { members, building the capacity of } \\
\text { partners and developing the existing } \\
\text { capacity in term of plant capacity, } \\
\text { technology inclusion is significant in }\end{array}$ & $\begin{array}{l}\text { Klassen and Vachon, 2003; } \\
\text { Markley and Davis, 2007; Lee, } \\
\text { 2008; Wu and Pagell, 2011; } \\
\text { Ageron et al., 2012; Grimm et al., } \\
2014\end{array}$ \\
\hline
\end{tabular}




\begin{tabular}{|c|c|c|}
\hline & sustainability adoption & \\
\hline $\begin{array}{l}\text { Monitoring and auditing the } \\
\text { ongoing supply chain activities } \\
\text { (E8) }\end{array}$ & $\begin{array}{l}\text { Monitoring and auditing ongoing } \\
\text { supply chain activities are important } \\
\text { to drive sustainability }\end{array}$ & $\begin{array}{l}\text { Florida, 1996; Zsidisin and } \\
\text { Hendrick, 1998; Rao and Holt, } \\
\text { 2005; Seuring and Muller, 2008; } \\
\text { Hong et al., 2009; Peters et al., } \\
2011\end{array}$ \\
\hline Competitive advantages (E9) & $\begin{array}{l}\text { Sustainable initiatives may provide } \\
\text { definite competitive advantage in } \\
\text { the market from an organizational } \\
\text { supply chain context }\end{array}$ & $\begin{array}{l}\text { Elkington, 1994; Vermeulen and } \\
\text { Ras, 2006; Walker et al, 2008, } \\
\text { Nakano and Hirao, 2011; Ageron } \\
\text { et al., } 2012\end{array}$ \\
\hline $\begin{array}{l}\text { Cost effectiveness } \\
\text { improvements in and } \\
\text { performance (E10) }\end{array}$ & $\begin{array}{l}\text { Sustainable initiatives may enable } \\
\text { progress of agricultural products } \\
\text { towards cost effectiveness, and } \\
\text { hence enhanced performance. }\end{array}$ & $\begin{array}{l}\text { Bowen et al., 2001; Simpson and } \\
\text { Power, 2005; Markley and Davis, } \\
\text { 2007; Mangla et al., 2014, Luthra } \\
\text { et al., } 2015\end{array}$ \\
\hline
\end{tabular}

\subsection{Research gaps and highlights}

A-FSC has emerged as a significant global issue and it is anticipated that developed nations will enhance their agricultural production and effectiveness to respond to the rise in the overall food demand (FAO, 2006, 2009; Sakschewski et al., 2014). Yet, there is a perceived lack of effectiveness in agricultural production in developing nations (Birthal et al., 2015). In parallel, developing nations like India also suffer inefficiencies despite the agriculture sector being a primary source of national employment (Dev et al., 2014). Fears concerning the scarcity of natural resources (in the near future) and shortages of supply may rise. Other issues include increasing demand for proven sustainability practices in the agri-food sector even in developing nations. Food wastage and supply chain losses, information distortion, poor infrastructure and capacity planning were all identified as other significant issues which negatively impacted on sustainability (Zanoni and Zavanella, 2012; Li et al., 2014; Grimm et al., 2014; Sgarbossa and Russo, 2017). It is noted that exact figure on wastage of food in India is difficult to establish with accuracy yet the Food and Agriculture Organization (FAO) estimated that approximately 45\% of fruit and vegetables (post-harvest to distribution) were wasted in developing Asian countries like India (2011 baseline).

The utilization of resources and the storage and transportation of agricultural food products provide a very good opportunity to understand the environment related problems that are hampering sustainable development. In line with this, A-FSC is also acknowledged as one of the significant domains in the European Union (EU) with important implications for sustainable 
development. Some of the implications of sustainability are given as the fulfillment of societal needs, financial benefits, ecological impacts, prosperity and new business opportunities (Humphrey and Memedovic, 2006). To meet these challenges, an organization must seek to adopt sustainability related practices in the agri-food sector (Beske and Seuring, 2014; Accorsi et al., 2016) and deploy strategies that are helpful in the effective implementation of such initiatives. The literature also revealed that the area of sustainability in A-FSC networks is comparatively unexplored (Ilbery et al., 2004; Stevens et al., 2016) and provides the motive to conduct this research in the A-FSC scenario.

This research combines an ISM - fuzzy DEMATEL approach to evaluate the enablers for effective adoption of sustainability concepts in A-FSCs. This research work contributes to extant knowledge by -

$>$ Identifying the enablers for effective adoption of sustainability in A-FSCs from the literature and expert inputs perspectives (for details see Section 4).

$>$ The finalized enablers were evaluated to examine the contextual relationships between them and understand their hierarchical relationships using ISM through the input of experts (for details see Section 4).

$>$ The finalized enablers were analyzed to divide them into cause and effect groups using fuzzy DEMATEL through expert input (for details see Section 5).

$>$ The managerial implications were explored to identify the issues related to sustainability management practice in the agri-food sector (for details see Section 6).

\section{Research Methods}

A combined ISM - fuzzy DEMATEL research methodology was designed and executed for this study (Mehregan et al., 2014). ISM is a methodical and interactive technique that relies on a group of independent professionals (Warfield, 1974) and helps in understanding the interrelationships between variables. The fuzzy DEMATEL methodology can uncover the relationships among the factors influencing other factors under unclear situations (Hsu et al., 2013; Lin et al., 2013). ISM and DEMATEL/fuzzy based DEMATEL techniques are superior to other interpretive and decision modeling techniques, such as Analytic Hierarchy Process (AHP), Analytic Network Process (ANP), Graph theory, Structural Equation modeling (SEM), Interpretive Ranking Process (IRP) etc. Table 2 provides a brief comparison of ISM- 
DEMATEL/Fuzzy DEMATEL with above listed approaches (Wagner and Neshat, 2010; Raj et al., 2010; Rahman and Subramanian, 2012; Mathiyazhagan et al., 2013; Jakhar and Barua, 2014; Mangla et al., 2015; Luthra et al., 2016b; Luthra et al., 2017).

Table 2: Comparison of ISM-DEMATEL/Fuzzy DEMATEL with other interpretive and modeling techniques

\begin{tabular}{|c|c|c|c|c|c|c|}
\hline $\begin{array}{l}\text { ISM and } \\
\text { MICMAC }\end{array}$ & $\begin{array}{l}\text { DEMATEL/ } \\
\text { Fuzzy } \\
\text { DEMATEL }\end{array}$ & Graph Theory & AHP & ANP & SEM & IRP \\
\hline $\begin{array}{l}\text { ISM helps } \\
\text { in revealing } \\
\text { the } \\
\text { contextual } \\
\text { relations } \\
\text { among the } \\
\text { factors. } \\
\text { MISMAC } \\
\text { analysis } \\
\text { evaluates } \\
\text { the factors } \\
\text { using their } \\
\text { driving and } \\
\text { dependence } \\
\text { power. }\end{array}$ & $\begin{array}{l}\text { DEMATEL } \\
\text { assists in } \\
\text { revealing the } \\
\text { causal } \\
\text { relations } \\
\text { among the } \\
\text { factors. } \\
\text { Compared to } \\
\text { DEMATEL, } \\
\text { fuzzy blend } \\
\text { DEMATEL is } \\
\text { very useful in } \\
\text { managing with } \\
\text { human } \\
\text { subjectivity } \\
\text { and } \\
\text { unclearness in } \\
\text { data while } \\
\text { evaluating the } \\
\text { factors for } \\
\text { their causal } \\
\text { relations. }\end{array}$ & $\begin{array}{l}\text { Graph theory } \\
\text { reveals the } \\
\text { interdependence } \\
\text { among the } \\
\text { factors, with } \\
\text { limited } \\
\text { applicability } \\
\text { due to } \\
\text { reliability issues } \\
\text { in deciding the } \\
\text { direction of } \\
\text { relationships } \\
\text { between the } \\
\text { factors. }\end{array}$ & $\begin{array}{l}\text { AHP } \\
\text { assists in } \\
\text { drawing } \\
\text { the } \\
\text { hierarchical } \\
\text { structure of } \\
\text { factors but } \\
\text { fails on the } \\
\text { part of } \\
\text { consistency } \\
\text { in expert's } \\
\text { feedback. }\end{array}$ & $\begin{array}{l}\text { ANP assists in } \\
\text { revealing the } \\
\text { interdependence } \\
\text { among the } \\
\text { factors and } \\
\text { manages the } \\
\text { issue of } \\
\text { consistency as } \\
\text { well. However, } \\
\text { ANP has } \\
\text { limited } \\
\text { applicability } \\
\text { due to its } \\
\text { complex } \\
\text { procedure. }\end{array}$ & $\begin{array}{l}\text { SEM } \\
\text { helps in } \\
\text { theory } \\
\text { building } \\
\text { and } \\
\text { primarily } \\
\text { used for } \\
\text { validation. } \\
\text { However, } \\
\text { SEM } \\
\text { needs } \\
\text { large } \\
\text { sample } \\
\text { size to } \\
\text { apply. }\end{array}$ & $\begin{array}{l}\text { IRP not only } \\
\text { helps in } \\
\text { determining the } \\
\text { relative } \\
\text { importance of } \\
\text { factors but also } \\
\text { assists in } \\
\text { understanding the } \\
\text { interpretive logic } \\
\text { between two } \\
\text { factors. However, } \\
\text { IRP has limited } \\
\text { applicability for } \\
\text { pairwise matrix } \\
\text { of more than } 9 \times \\
9 .\end{array}$ \\
\hline
\end{tabular}

The ISM and fuzzy DEMATEL were combined in this study due to the following reasons (Chuang et al., 2013; Mehregan et al., 2014; dos Muchangos et al., 2015) -

$>$ ISM and fuzzy DEMATEL are capable in illustrating complex relationships between the variables considered in decision-making under uncertain surroundings.

Combination of ISM and fuzzy DEMATEL can reveal the cause and effect relation among considered decision variables (through driving and dependence power in ISM and the prominence and relation in fuzzy DEMATEL).

$>$ Their combined use can assist in understanding the level of importance of considered decision variables through well described diagrams (ISM based hierarchical diagram and causal diagram in fuzzy DEMATEL). 
In ISM, we consider four probable relations to analyze the interactions among the decision variables; however, we could not distinguish the strength of the contextual relations among the decision variables using ISM. While fuzzy DEMATEL can investigate the relations deeper even capture the strength of the contextual relations through a sophisticated scale (from 0 to 4 ) under unclear surroundings.

ISM can only be combined with DEMATEL to know the direction and level, in the complex causal relationship, without prioritization of the important factors; thus, a comprehensive feedback system considers the importance and the relations among factors.

ISM is a macro-oriented whereas DEMATEL balances this with a micro-oriented focus (dos Muchangos et al., 2015). Thus, in this work, the combined ISM - fuzzy DEMATEL technique is preferred to evaluate the macro and micro relationships and understanding of enablers to accomplish sustainability orientation in A-FSCs under vague surroundings.

We preferred to use fuzzy logic with the DEMATEL and not with ISM - MICMAC, due to several reasons (Gorane and Kant, 2013; Mehregan et al., 2014; Yadav and Desai, 2017). Some of them are - (i) based on objectives of this work and subsequent discussion with the experts; (ii) several researchers have supported in literature that inclusion of fuzzy set theory in ISMMICMAC can beneficial when large number of variables are included for application purposes. Currently, ten key enablers are included for the present research work; (iii) ISM - MICMAC analysis helps in addressing the binary type of relationships among the considered enablers, being pursued in this work. However, the relationship between these enablers cannot be always equal. Some relations may be strong, some may be especially strong and some relations may be better. In this sense, we can extend fuzzy concepts to increase the sensitivity of traditional ISM MICMAC analysis (Yadav and Desai, 2017). For this, expert opinions can be used to derive the relationships between the enablers through fuzzy direct relation matrix. In our case, we discussed the situation of stabilizing the matrix with experts and possibility of mixing fuzzy concepts with ISM - MICMAC. However, experts selected in our study are highly skilled in decision making and applying interpretive structural techniques. The reason was explained as for the present problem there won't be much deviation in the results obtained in this work. In this sense, the use of combined ISM - MICMAC and fuzzy DEMATEL would make this study simpler for the 
readers/managers to understand and manage sustainability initiatives in food value chains in Indian context or other developing nation's with marginal modification. However, the extension of fuzzy theory with ISM-MICAMC can be explored in future (as mentioned in future scope of research, Section 7).

Further, a very limited use of this combined ISM-fuzzy DEMATEL has been undertaken by previous studies (Chuang et al., 2013; dos Muchangos et al., 2015). In this sense, the present research is a very initial attempt to combine ISM - Fuzzy DEMATEL technique in developing sustainability driven implications in an Agri-food value chain context.

\subsection{Interpretive Structural Modelling (ISM)}

ISM is a useful technique to identify and summarize relationships among specific factors (Warfield, 1974) as it establishes interrelationships among poorly communicated and unstructured variables based on expert opinion (Mandal and Deshmukh, 1994). ISM is an interpretive way of judging different elements as to how they are related in any process (Mangla et al., 2013) and structures complicated sets of factors based on their mutual relationships (Kumar and Rahman, 2013).

Researchers have used ISM methodology to analyze various issues such as reverse logistics adoption (Ravi and Shankar, 2005), green value chains (Mathiyazhagan et al., 2013; Mangla et al., 2014), product recovery systems (Mangla et al., 2012), total quality management implementation (Talib et al., 2011), total productive maintenance implementation (Singh et al., 2014) and sustainable value chains (Luthra et al., 2015). The ISM has several steps (Warfield, 1974) as follows:

1) Formation of a structural self-interaction matrix (SSIM) to analyze contextual relationships among identified enablers to implement sustainable initiatives in A-FSC.

2) Development of an initial reachability matrix from SSIM, and transitivity is checked to form the final reachability matrix. Here transitivity is assumed to be present and is the basic step for applying the ISM technique.

3) Formation of the final reachability matrix to partition various levels of identified enablers.

4) Formation of a digraph on removing the all transitivity links.

5) Formation of an ISM model from the developed digraph. 
6) Assessment of the conceptual consistency of the formed ISM model, making necessary modifications, if required.

\subsection{Fuzzy DEMATEL}

The DEMATEL technique is suitable for exploring complex causal relationships and intertwined problem groups (Fontela and Gabus, 1976). DEMATEL helps to obtain direct and indirect influences among criteria in multi criteria decision problems. It also helps in computing the relationship and strength among the factors involved (Gandhi et al., 2015). The DEMATEL methodology can assist in categorizing variables into cause and effect groups (Wu, 2012; Hsu et al., 2013; Mangla et al., 2016). However, DEMATEL application is limited in dealing with problems of uncertainties, inexactness of data and the subjectivity/bias associated with human judgment (Rahman and Subramanian, 2012). Thus, we prefer fuzzy DEMATEL in this study (Lin, 2013; Patil and Kant, 2014; Luthra et al., 2016a). The fuzzy DEMATEL has several steps as follows (for more details on steps please refer the Appendix - A):

1. Form an expert panel and evaluation criteria. To begin with, we form an expert panel that helps in capturing their feedback. The key enablers (assessment criteria) to implement sustainable initiatives in the A-FSC are listed through literature.

2. Construct a fuzzy pair wise comparison matrix. The pairwise comparisons are obtained through expert's feedback using scale provided in Table 3. This further leads to initial direct relation matrix, and hence fuzzy matrix is developed accordingly (for more details please refer Appendix - A).

Table 3: Fuzzy linguistic scale (Modified Luthra et al., 2016b)

\begin{tabular}{l|l|l}
\hline Linguistic variable & Preference score & Corresponding TFNs \\
\hline No effect (No) & 0 & $(0,0,0.25)$ \\
\hline Very low effect (VL) & 1 & $(0,0.25,0.50)$ \\
\hline Low effect (L) & 2 & $(0.25,0.50,0.75)$ \\
\hline High effect (H) & 3 & $(0.50,0.75,1.0)$ \\
\hline Very high effect (VH) & 4 & $(0.75,1.0,1.0)$ \\
\hline
\end{tabular}

3. Develop the fuzzy average direct relation matrix (A), given by the expression as follows:

$$
\text { aij }=\frac{1}{k \sum x^{k_{i j}}}
$$

where, $\mathrm{k}$ is the number of experts and $\mathrm{I}$ and $\mathrm{j}$ are the criteria to be compared. 
In order to obtain crisp numbers, we performed defuzzification using weighted average method through Eq. (2).

$$
\mathrm{I}_{\mathrm{T}}=\frac{1}{6}(\mathrm{e}+4 \mathrm{f}+\mathrm{g})
$$

Where, e, f and $g$ represent the triangular fuzzy numbers.

4. Develop the normalized initial direct relation matrix (D) by means of subsequent Equations (3) and (4).

$$
\begin{aligned}
& \mathrm{m}=\min \left[\frac{1}{\max \sum_{\mathrm{j}=1}^{\mathrm{n}}\left|\mathrm{a}_{\mathrm{ij}}\right|}, \frac{1}{\max \sum_{\mathrm{i}=1}^{\mathrm{n}}\left|\mathrm{a}_{\mathrm{ij}}\right|}\right] \\
& \mathrm{D}=\mathrm{m} \times \mathrm{A}
\end{aligned}
$$

5. Develop the total-relation matrix by using Eq. (5) as provided below.

$$
\mathrm{T}=(\mathrm{I}-\mathrm{D})^{-1}
$$

$$
\text { Where, I: Identity matrix; T: Total relation matrix, } T=\left[t_{i j}\right]_{n \times n}
$$

6. Determine the summation of rows (R) and the summation of columns (C) by using Eq. (6) and Eq. (7) as given below:

$$
\begin{aligned}
& \mathrm{R}=\left\{\sum_{\mathrm{j}=1}^{\mathrm{n}} \mathrm{t}_{\mathrm{ij}}\right\}_{\mathrm{n} \times 1} \\
& \mathrm{C}=\left\{\sum_{\mathrm{i}=1}^{\mathrm{n}} \mathrm{t}_{\mathrm{ij}}\right\}_{1 \times \mathrm{n}}
\end{aligned}
$$

$\mathrm{R}$ stands for the net effects provided by one critical factor, say (i), to the other critical factor (j), and $\mathrm{C}$ represents the net effect received by critical factor (j) from the other critical factor (i).

7. Develop a cause and effect graph. This is plotted using the dataset $(\mathrm{R}+\mathrm{C} ; \mathrm{R}-\mathrm{C})$. Further based on the value of the dataset (R-C), we can classify the enablers into cause (if (R-C) is positive) and effect group (if (R-C) is negative).

\section{Proposed Research Framework}

Figure 1 shows the analytical framework to structure the enablers for sustainable initiative implementation, based on ISM, MICMAC and fuzzy DEMATEL techniques. The research consisted of three phases:

\subsection{Phase 1: Identification and Validation of the Enablers to Implement the Sustainable} Initiatives in A-FSC 
The literature survey and expert opinions were executed to identify important enablers to sustainable initiative implementation. Initially, enablers were identified through the literature review and later validated using expert review.

4.2. Phase 2: Analyzing Contextual Interactions between the Identified Enablers and their Hierarchical Levels to Accept the Sustainable Initiatives in A-FSC using ISM-MICAMC through Expert Panel Inputs

The ISM - Fuzzy MICMAC approach was applied to understand contextual relationships between the enablers and their hierarchical levels and the opinions of the expert panel were critical to testing these relationships.

4.3. Phase 3: Categorization of the Identified Enablers into Cause and Effect Groups to implement the Sustainable Initiatives in A-FSC using Fuzzy DEMATEL through Expert Panel Inputs

The identified enablers were further analyzed to determine the cause and effect groups (using fuzzy DEMATEL and expert panel input). This classification can enable managers to frame the decision strategies in order to achieve sustainability in A-FSC. 


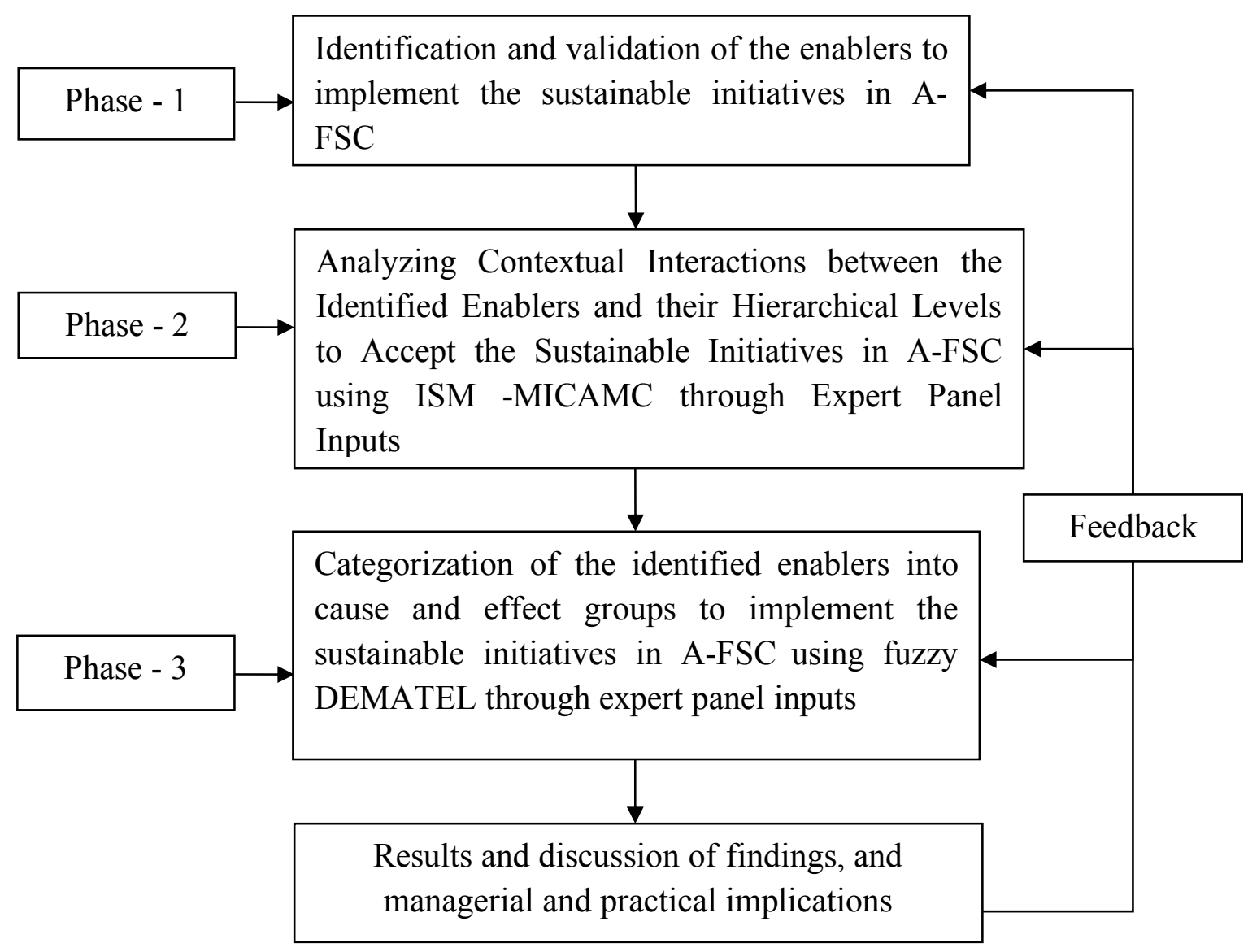

Figure 1: Proposed research framework

\section{Case Study}

The Agro Supply Chain was purposively selected as a case and is coded "ABC". It is one of the biggest national agri-food retail and distribution businesses. The company was established in the early 2000's, operates in more than 90 cities across India, with more than 600 stores. The company deals with the various products, such as fresh produce (vegetable and fruits), dairy products, and fast-moving consumer goods (FMCG), and serves more than 10 million consumers. Operations include the distribution, storage, transportation and retailing of the agri food products from farmers to end consumers.

The case has formally and strategically recognized the importance of sustainability due to competitive, public health, regulatory and community pressures. The company is a part of a project termed 'Sustainable Development of Supply Chains' and has also a mission to enhance its business and supply chain sustainability to:

- To raise the market value and economic gains. 
- To meet with the requirements of food demand and safety.

- To address the concern from social and ecological issues.

The case also sought to develop a structural model to analyze key enablers and contextual relationships that could support their mission and practice of sustainability (hence its purposive selection).

To support the practical objective of the case, an expert panel comprising of six professionals (one procurement manager, one production manager, one environmental engineer, two marketing managers and one logistics manager) was formed. The experts selected were highly skilled in decision making and applying interpretive structural techniques, particularly ISM. The experts were highly competent in the field of supply chain planning and operations management, each with engaged with the designed (phased) methodology as follows:

\subsection{Phase 1: Identification and Validation of the Enablers to Implement the Sustainable} Initiatives in A-FSC

Ten important enablers were identified from the literature and presented for expert review. They were asked to finalize the enablers and were free to delete or add to the list. The experts showed common agreement with the literature based enablers and no suggestions were received to amend the list. A total of 10 key enablers relevant to the implementation of sustainability initiatives in A-FSC were selected.

5.2 Phase 2: Analyzing Contextual Interactions between the Identified Enablers and their Hierarchical Levels to Accept the Sustainable Initiatives in A-FSC using ISM -MICAMC through Expert Panel Inputs

The ISM - MICMAC approach was utilized for problem evaluation. The expert panel constructed the SSIM matrix of enablers and established the contextual relationships among the enablers ( $i$ and $j$ ) using pair-wise comparisons. Notations were provided to the experts to help them in framing the required contextual relationships between the two enablers, given as:

$\mathrm{V}=$ Enabler (i) will assist reach CF (j); A = Enabler (j) will help reach CF (i)

$\mathrm{X}=$ Enablers (i) and (j) will assist reach each other and $\mathrm{O}=$ Enablers (i) and (j) are not linked. 
Thus, the SSIM was developed for the enablers to implement sustainable initiatives in the AFSC, as depicted in Table 4.

Table 4: SSIM for enablers to implement sustainable initiatives in A-FSC

\begin{tabular}{|c|c|c|c|c|c|c|c|c|c|}
\hline Enablers & 10 & 9 & 8 & 7 & 6 & 5 & 4 & 3 & 2 \\
\hline $\begin{array}{l}\text { Pressure by various governmental, regulating agencies and non- } \\
\text { government bodies (E1) }\end{array}$ & $\mathrm{V}$ & $\mathrm{O}$ & $\mathrm{V}$ & $\mathrm{V}$ & $\mathrm{V}$ & $\mathrm{V}$ & $\mathrm{V}$ & $\mathrm{X}$ & $\mathrm{V}$ \\
\hline $\begin{array}{l}\text { Incentives and support of various agencies to undertake sustainable } \\
\text { initiatives (E2) }\end{array}$ & $\mathrm{V}$ & $\mathrm{V}$ & $\mathrm{O}$ & $\mathrm{O}$ & $\mathrm{O}$ & $\mathrm{V}$ & $\mathrm{X}$ & A & \\
\hline Understanding customer and other stakeholder requirements (E3) & $\mathrm{V}$ & $\mathrm{V}$ & $\mathrm{V}$ & $\mathrm{O}$ & $\mathrm{O}$ & $\mathrm{V}$ & $\mathrm{V}$ & & \\
\hline Understanding the sustainability initiative importance and benefits (E4) & $\mathrm{V}$ & $\mathrm{V}$ & $\mathrm{V}$ & $\mathrm{V}$ & $\mathrm{V}$ & $\mathrm{V}$ & & & \\
\hline Management involvement, support and commitment (E5) & $\mathrm{V}$ & $\mathrm{V}$ & $\mathrm{V}$ & $\mathrm{V}$ & $\mathrm{V}$ & & & & \\
\hline $\begin{array}{l}\text { Resources allocation and information sharing within and across the } \\
\text { hierarchy (E6) }\end{array}$ & $\mathrm{V}$ & $\mathrm{V}$ & A & $\mathrm{X}$ & & & & & \\
\hline $\begin{array}{l}\text { Joint efforts, planning and capacity building for delivering sustainability } \\
\text { focused products (E7) }\end{array}$ & $\mathrm{V}$ & $\mathrm{V}$ & A & & & & & & \\
\hline Monitoring and auditing the ongoing supply chain activities (E8) & $\mathrm{V}$ & $\mathrm{V}$ & & & & & & & \\
\hline Competitive advantages (E9) & $\mathrm{X}$ & & & & & & & & \\
\hline Cost effectiveness and improvements in overall performance (E10) & - & & & & & & & & \\
\hline
\end{tabular}

A matrix was formed from the SSIM and indicated the relationships between the enablers in binary form (digits 0 and 1). We used several definite rules to construct the initial reachability matrix (for details please refer the studies of Mangla et al., 2013).

Thus, the initial reachability matrix was developed for the enablers to implement sustainable initiatives in A-FSC, and is depicted in Appendix - B. A final reachability matrix was formed incorporating the transitivity relations among the enablers. Transitivity is used to assess each factor against all others. For instance, enabler E1 shows the relation to enabler E2, and enabler E2 shows the relation to enabler E9, then enabler E1 must have a relation to enabler E9. The final reachability matrix is developed for the enablers to implement sustainable initiatives in AFSC and is depicted in Table 5. The transitivity is marked as $1^{\mathrm{a}}$.

Table 5: Final reachability matrix for enablers to implement sustainable initiatives in A-FSC

\begin{tabular}{c|c|c|c|c|c|c|c|c|c|c|c}
\hline Enablers & $\mathbf{1}$ & $\mathbf{2}$ & $\mathbf{3}$ & $\mathbf{4}$ & $\mathbf{5}$ & $\mathbf{6}$ & $\mathbf{7}$ & $\mathbf{8}$ & $\mathbf{9}$ & $\mathbf{1 0}$ & Driving power \\
\hline E1 & 1 & 1 & 1 & 1 & 1 & 1 & 1 & 1 & $1^{\mathrm{a}}$ & 1 & 10 \\
\hline E2 & 0 & 1 & 0 & 1 & 1 & $1^{\mathrm{a}}$ & $1^{\mathrm{a}}$ & $1^{\mathrm{a}}$ & 1 & 1 & 08 \\
\hline E3 & 1 & 1 & 1 & 1 & 1 & $1^{\mathrm{a}}$ & $1^{\mathrm{a}}$ & 1 & 1 & 1 & 10 \\
\hline E4 & 0 & 1 & 0 & 1 & 1 & 1 & 1 & 1 & 1 & 1 & 08 \\
\hline E5 & 0 & 0 & 0 & 0 & 1 & 1 & 1 & 1 & 1 & 1 & 06 \\
\hline E6 & 0 & 0 & 0 & 0 & 0 & 1 & 1 & 0 & $1^{\mathrm{a}}$ & $1^{\mathrm{a}}$ & 04 \\
\hline E7 & 0 & 0 & 0 & 0 & 0 & 1 & 1 & 0 & 1 & 1 & 04 \\
\hline E8 & 0 & 0 & 0 & 0 & 0 & 1 & 1 & 1 & 1 & 1 & 05 \\
\hline E9 & 0 & 0 & 0 & 0 & 0 & 0 & 0 & 0 & 1 & 1 & 02 \\
\hline
\end{tabular}




\begin{tabular}{c|c|c|c|c|c|c|c|c|c|c|c}
\hline E10 & 0 & 0 & 0 & 0 & 0 & 0 & 0 & 0 & 1 & 1 & 02 \\
\hline Dependency power & 02 & 04 & 02 & 04 & 05 & 08 & 08 & 06 & 10 & 10 & $\mathbf{5 9 / 5 9}$ \\
\hline
\end{tabular}

Partitioning was conducted to determine the hierarchical level of enablers. The reachability and antecedent sets for each enabler were obtained using the final reachability matrix (Warfield, 1974) and next, the intersection between reachability and the antecedent set was obtained. If the reachability set and the intersection set have the same values then highest rank or level is assigned to that enabler, and the particular enabler is eliminated from subsequent iterations. This procedure is repeated to produce the final iteration (See Appendix - B for the iteration 1 of enablers). A total of six iterations were performed to obtain the level of each enabler (for details see Table 6 .

Table 6: Iteration II-VI for enablers to implement sustainable initiatives in A-FSC

\begin{tabular}{l|l|l|l|l|c}
\hline Iteration & Enabler & Reachability Set & Antecedents Set & Intersection Set & Level \\
\hline I & E9,E10 & 9,10 & $1,2,3,4,5,6,7,8,9,10$ & 9,10 & 1 \\
\hline II & E6,E7 & 6,7 & $1,2,3,4,5,6,7,8$ & 6,7 & 2 \\
\hline III & E8 & 8 & $1,2,3,4,5,8$ & 8 & 3 \\
\hline IV & E5 & 5 & $1,2,3,4,5$ & 5 & 4 \\
\hline V & E2,E4 & 2,4 & $1,2,3,4$ & 2,4 & 5 \\
\hline VI & E1,E3 & 1,3 & 1,3 & 1,3 & 6 \\
\hline
\end{tabular}

Six levels were identified by partitioning (Table 6). Based on the final reachability matrix and the final levels of the enablers, a hierarchical structural model for the enablers for sustainability implementation was constructed (Figure 2). 


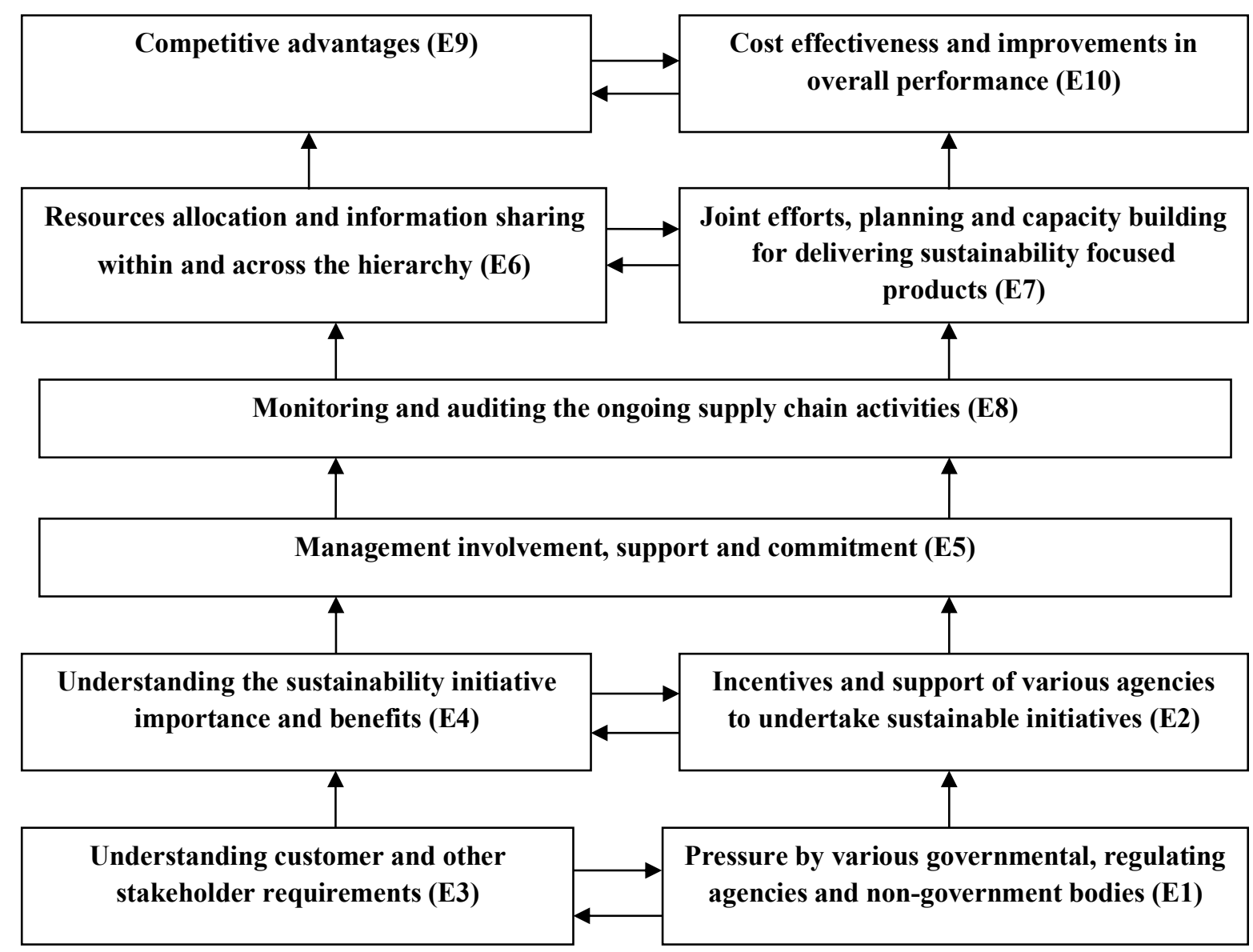

Figure 2: ISM based hierarchical model for enablers to implement sustainable initiatives in A-FSCs

The findings show 'Pressure by various governmental, regulating agencies and non-government bodies (E1)' and 'Understanding the customer and other stakeholders' requirements (E3)' are the most important independent enablers to implementation. Pressure by various governmental, regulating agencies, non-government bodies, understanding customer and other stakeholder requirements may help to 'Understand the sustainability initiative importance and benefits (E4)', which may further seek for 'Incentives and support of various agencies to undertake sustainable initiatives (E2)' for agricultural based products. This helps an understanding of sustainability initiatives importance and assists the promotion of support from various agencies to motivate company management to take necessary sustainability practices.

Likewise, 'Management involvement, support and commitment (E5)' and 'Monitor and audit the ongoing supply chain activities (E8)' to make improvements in sustainability oriented decisions 
were also important. Monitoring/auditing ongoing supply chain activities are hypothesized to achieve efficient 'Resources allocation and information sharing within and across the hierarchy (E6)'. 'Joint efforts, planning and capacity building for delivering sustainability focused products (E7)' to build more sustainable systems reinforce these improvement and can support 'Competitive advantages (E9)' and 'Cost effectiveness and improvements in overall performance (E10)' to implement sustainable initiatives in A-FSCs.

The MICMAC analysis was used to classify the enablers into four regions (Figure 3) to show the dependence of the enablers.

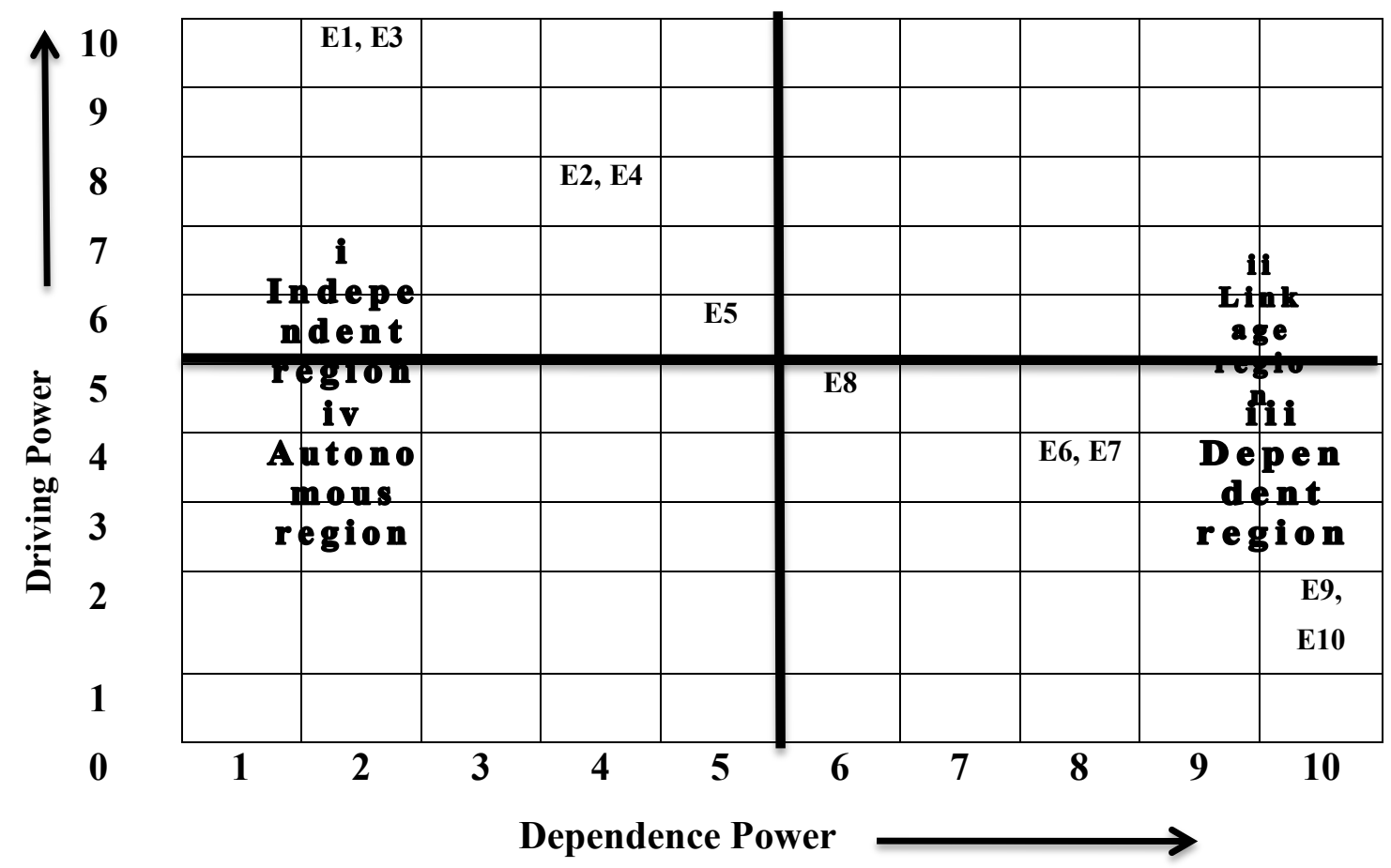

Figure 3: MICMAC analysis for enablers to implement sustainable initiatives in A-FSC

\section{Four regions are identified as:}

The Independent region has five enablers i.e. E1, E3, E2, E4 and E5 (see Figure 3) of less dependence but high driving power and is termed "key enablers". They form the bottom of the structural model. Next, is the Linkage region, and no enablers is recognized with high driving and dependence power. Such Enablers are generally unstable in nature.

The Dependent region has five enablers i.e. E8, E6, E7, E9 and E10. These enablers have high dependence and less driving power, and are the desired outcomes. They occupy the top position of the structural model and exhibit strong dependence of key enablers (they need all the other 
key enablers to diminish the effect of these key enablers during implementation of sustainable initiatives).

Lastly, the Autonomous region contains no enablers. This region has less driving and dependence power. These key enablers lie close to origin in the figure and are comparatively disconnected to the entire system. In the present work, no enabler comes in this region.

5.3. Phase 3: Categorization of the Identified Enablers into Cause and Effect Groups to implement the Sustainable Initiatives in A-FSC using Fuzzy DEMATEL through Expert Panel Inputs

Fuzzy DEMATEL was employed and an expert panel selected and organized the identified enablers into cause and effect groups for sustainability implementation initiatives. A brainstorming session was undertaken to make pair-wise comparisons between enablers using a scale (See Table 3) and the assessment is presented in Appendix - C. The fuzzy direct relation matrix for enablers to implement sustainable initiatives in A-FSC is shown in Table 7.

Table 7: Fuzzy initial direct relation matrix for enablers to implement sustainable initiatives in A-FSC

\begin{tabular}{c|c|c|c|c|c|c|c|c|c|c}
\hline Enablers & $\mathbf{1}$ & $\mathbf{2}$ & $\mathbf{3}$ & $\mathbf{4}$ & $\mathbf{5}$ & $\mathbf{6}$ & $\mathbf{7}$ & $\mathbf{8}$ & $\mathbf{9}$ & $\mathbf{1 0}$ \\
\hline E1 & 0.04 & 0.75 & 0.75 & 0.75 & 0.75 & 0.75 & 0.96 & 0.75 & 0.96 & 0.96 \\
\hline E2 & 0.50 & 0.04 & 0.75 & 0.75 & 0.50 & 0.75 & 0.96 & 0.96 & 0.75 & 0.96 \\
\hline E3 & 0.75 & 0.75 & 0.04 & 0.96 & 0.75 & 0.75 & 0.75 & 0.75 & 0.96 & 0.96 \\
\hline E4 & 0.75 & 0.75 & 0.75 & 0.04 & 0.50 & 0.75 & 0.75 & 0.96 & 0.96 & 0.75 \\
\hline E5 & 0.50 & 0.75 & 0.50 & 0.75 & 0.04 & 0.75 & 0.75 & 0.96 & 0.75 & 0.75 \\
\hline E6 & 0.50 & 0.50 & 0.50 & 0.50 & 0.75 & 0.04 & 0.75 & 0.50 & 0.50 & 0.75 \\
\hline E7 & 0.50 & 0.50 & 0.50 & 0.50 & 0.75 & 0.50 & 0.04 & 0.50 & 0.75 & 0.75 \\
\hline E8 & 0.50 & 0.50 & 0.50 & 0.75 & 0.75 & 0.75 & 0.75 & 0.04 & 0.96 & 0.96 \\
\hline E9 & 0.75 & 0.50 & 0.50 & 0.25 & 0.50 & 0.75 & 0.50 & 0.25 & 0.04 & 0.25 \\
\hline E10 & 0.50 & 0.50 & 0.50 & 0.50 & 0.50 & 0.75 & 0.50 & 0.25 & 0.25 & 0.04 \\
\hline
\end{tabular}

In the next step, the fuzzy normalized direct-relation matrix of the enablers was developed (see Appendix- C) using Eqs. (3) and (4). The total direct relation matrix for implementation enablers using Eq. (5) is presented in Table 8.

Table 8: Fuzzy total direct relation matrix for enablers to implement sustainable initiatives in A-FSC

\begin{tabular}{c|c|c|c|c|c|c|c|c|c|c}
\hline Enablers & $\mathbf{1}$ & $\mathbf{2}$ & $\mathbf{3}$ & $\mathbf{4}$ & $\mathbf{5}$ & $\mathbf{6}$ & $\mathbf{7}$ & $\mathbf{8}$ & $\mathbf{9}$ & $\mathbf{1 0}$ \\
\hline E1 & 0.37 & 0.47 & 0.46 & 0.48 & 0.49 & 0.54 & 0.57 & 0.49 & 0.58 & 0.60 \\
\hline E2 & 0.41 & 0.36 & 0.43 & 0.46 & 0.44 & 0.51 & 0.54 & 0.49 & 0.52 & 0.57 \\
\hline E3 & 0.46 & 0.48 & 0.37 & 0.51 & 0.49 & 0.54 & 0.55 & 0.49 & 0.58 & 0.60 \\
\hline E4 & 0.44 & 0.45 & 0.44 & 0.38 & 0.44 & 0.52 & 0.52 & 0.49 & 0.56 & 0.55 \\
\hline E5 & 0.39 & 0.43 & 0.39 & 0.44 & 0.36 & 0.49 & 0.50 & 0.47 & 0.50 & 0.52 \\
\hline
\end{tabular}




\begin{tabular}{c|l|l|l|l|l|l|l|l|l|l}
\hline E6 & 0.33 & 0.34 & 0.33 & 0.35 & 0.39 & 0.33 & 0.43 & 0.36 & 0.40 & 0.44 \\
\hline E7 & 0.33 & 0.34 & 0.33 & 0.35 & 0.38 & 0.39 & 0.34 & 0.35 & 0.43 & 0.44 \\
\hline E8 & 0.38 & 0.39 & 0.38 & 0.43 & 0.44 & 0.48 & 0.48 & 0.35 & 0.51 & 0.53 \\
\hline E9 & 0.32 & 0.30 & 0.29 & 0.27 & 0.31 & 0.37 & 0.34 & 0.28 & 0.29 & 0.33 \\
\hline E10 & 0.29 & 0.30 & 0.29 & 0.30 & 0.31 & 0.37 & 0.34 & 0.28 & 0.32 & 0.30 \\
\hline
\end{tabular}

In the next step, the summation of rows $(\mathrm{R})$ and the summation of columns $(\mathrm{C})$ for enablers were computed using Equations. (6) and (7). Datasets $(\mathrm{R}+\mathrm{C})$ and $(\mathrm{R}-\mathrm{C})$ datasets for enablers to implement sustainable initiatives in A-FSC were calculated, as shown in Table 9.

Table 9: $(\mathrm{R}+\mathrm{C})$ and $(\mathrm{R}-\mathrm{C})$ datasets for enablers to implement sustainable initiatives in A-FSC

\begin{tabular}{c|c|c|c|c|c|c|c}
\hline Enablers & $\mathbf{R}$ & $\mathbf{C}$ & $\mathbf{R}+\mathbf{C}$ & $\begin{array}{c}\text { Rank based } \\
\text { on } \mathbf{R}+\mathbf{C}\end{array}$ & $\mathbf{R}-\mathbf{C}$ & $\begin{array}{c}\text { Rank based } \\
\text { on R-C }\end{array}$ & Cause/Effect \\
\hline E1 & 5.05 & 3.74 & 8.79 & $1^{\text {st }}$ & 1.32 & $2^{\text {nd }}$ & Cause \\
\hline E2 & 4.73 & 3.87 & 8.60 & $3^{\text {rd }}$ & 0.87 & $3^{\text {rd }}$ & Cause \\
\hline E3 & 5.08 & 3.71 & 8.79 & $1^{\text {st }}$ & 1.37 & $1^{\text {st }}$ & Cause \\
\hline E4 & 4.80 & 3.97 & 8.77 & $2^{\text {nd }}$ & 0.83 & $4^{\text {th }}$ & Cause \\
\hline E5 & 4.49 & 4.06 & 8.55 & $4^{\text {th }}$ & 0.42 & $5^{\text {th }}$ & Cause \\
\hline E6 & 3.70 & 4.55 & 8.25 & $8^{\text {th }}$ & -0.85 & $7^{\text {th }}$ & Effect \\
\hline E7 & 3.68 & 4.61 & 8.30 & $7^{\text {th }}$ & -0.93 & $8^{\text {th }}$ & Effect \\
\hline E8 & 4.38 & 4.05 & 8.44 & $6^{\text {th }}$ & 0.33 & $6^{\text {th }}$ & Cause \\
\hline E9 & 3.11 & 4.69 & 7.80 & $10^{\text {th }}$ & -1.59 & $9^{\text {th }}$ & Effect \\
\hline E10 & 3.10 & 4.87 & 7.97 & $9^{\text {th }}$ & -1.77 & $10^{\text {th }}$ & Effect \\
\hline
\end{tabular}

Further, the importance order of the enablers for successful implementation of sustainability in A-FSCs was obtained through $(\mathrm{R}+\mathrm{C})$ dataset (Rahman and Subramanian, 2012). This importance order is given as Pressure by various governmental, regulating agencies and nongovernment bodies (E1) -Understanding customer and other stakeholder requirements (E3) Understanding the sustainability initiative importance and benefits (E4) -Incentives and support of various agencies to undertake sustainable initiatives (E2) - Management involvement, support and commitment (E5) - Monitoring and auditing the ongoing supply chain activities (E8) - Joint efforts, planning and capacity building for delivering sustainability focused products (E7) Resources allocation and information sharing within and across the hierarchy (E6) - Cost effectiveness and improvements in overall performance (E10) - Competitive advantages (E9). Next, the cause and effect diagram for the enablers is constructed (presented in Figure 4). 


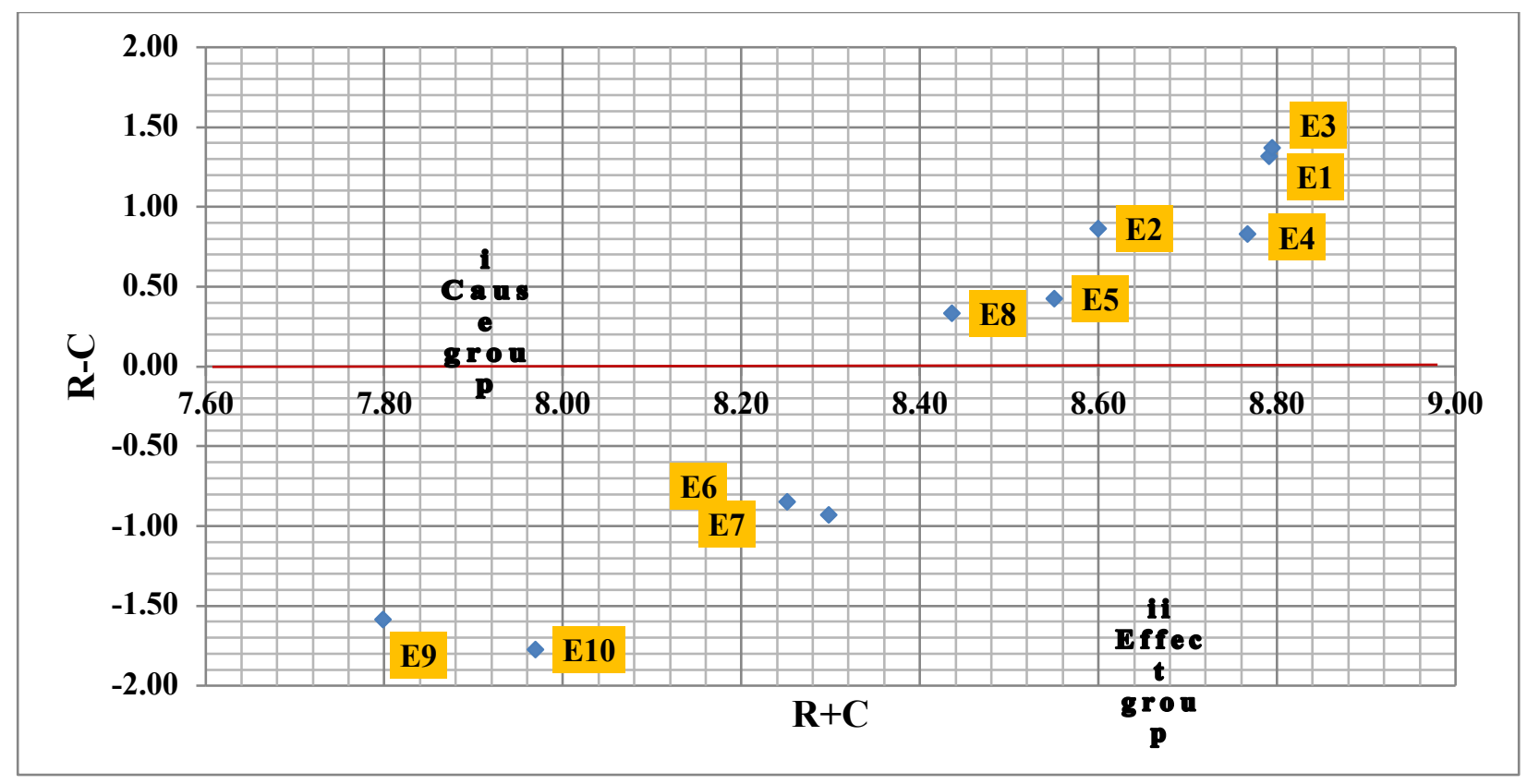

Figure 4: The cause and effect diagram for enablers to implement sustainable initiatives in A-FSC

\section{Discussions}

MICMAC analysis was carried out for validation of hierarchal structural model of the identified implementation enablers and five enablers ('Pressure by various governmental, regulating agencies and non-government bodies (E1)'; 'Incentives and support of various agencies to undertake sustainable initiatives (E2); 'Understanding customer and other stakeholder requirements (E3)'; 'Understanding the sustainability initiative importance and benefits (E4)' and 'Management involvement, support and commitment (E5)') were recognized as independent enablers. Based on (R-C) dataset in fuzzy DEMATEL, six enablers ('Pressure by various governmental, regulating agencies and non-government bodies (E1)'; 'Incentives and support of various agencies to undertake sustainable initiatives (E2); 'Understanding customer and other stakeholder requirements (E3)'; 'Understanding the sustainability initiative importance and benefits (E4)'; 'Management involvement, support and commitment (E5)' and 'Resources allocation and information sharing within and across the hierarchy (E6)') belongs to the cause group, and needs to be worked upon for sustainability implications in A-FSCs. The cause group enablers may be understood as independent enablers, which have direct impact on the system and high priority. 'Understanding customer and other stakeholder requirements (E3)' has the topmost $(\mathrm{R}-\mathrm{C})$ score of 1.37 and topmost $(\mathrm{R}+\mathrm{C})$ score of 8.79 , which imply that E3 is highly 
influential enabler. Chkanikova and Lehner, (2015) suggested in their research that customer requirements understanding and their responses on sustainable agriculture products is critical in developing sustainability related capabilities in supply chains. This suggests that it is necessary for the case organization to understand customers and other stakeholders' requirements to implement sustainable initiatives in A-FSCs. The second highest (R-C) score of 1.32 and $(\mathrm{R}+\mathrm{C})$ score of 8.79 is 'Pressure by various governmental, regulating agencies and nongovernment bodies (E1)'. This means that governments, regulating agencies and nongovernment bodies' relatively have higher impact in adopting sustainability in agri-food value chains in Indian context. 'Incentives and support of various agencies to undertake sustainable initiatives (E2)', with (R-C) score of 0.65 has third rank representing its impact on the system and $(\mathrm{R}+\mathrm{C})$ score of 8.60 on the overall system in implementing sustainable initiatives in AFSCs. Darbari et al. (2018) analyzed the impediments to sustainability in the food supply chain of India. The outcome of the analysis showed that "lack of governmental leadership in outlining the vision for sustainability and responsibilities of food retailers" and "lack of financial resources" were reported the major hurdles in implementing sustainable practices in A-FSC. At present, the case company is not facing any pressure by various governmental, regulating agencies and non-government bodies. Sustainability is very difficult when there are no pressures and incentives. It has also been supported in previous studies that government regulations and customer expectations play an influential role in sustainable business development (Al Zaabi et al., 2013; Bloom, 2015). Researchers suggested that pressures as well as incentives are needed from governmental as well as non-governmental agencies to motivate sustainable initiatives in the agri-food sector (Bloom, 2015). As such, the enablers in the cause group based on their impact can be given as the 'Understanding the sustainability initiative importance and benefits (E4)', with (R-C) score of 0.83, helps in developing research and development practices in sustainable agri-food value chains (Cagliano et al., 2016). Next, 'Management involvement, support and commitment (E5)' is very important to make efficient resource allocation and enable sharing of strategic information for eco-friendly practices among supply chain members (Yakovleva et al., 2012). Managers should continuously observe these enablers at each stage of sustainable initiative implementation. This could be supported by the research of Ageron, et al. (2012) that top management play an imperative part in accepting sustainable initiatives in business organizations. 'Monitoring and auditing the ongoing supply chain activities (E8)' with 
(R-C) score of 0.33 , will help in auditing quality requirements of the product required and monitoring sustainability requirement in implementing sustainable initiatives in A-FSCs (Djekic et al., 2016).

Thus, the case organization needs to concentrate on independent (cause group) enablers more carefully and might be treated as the origin of all the other (effect group) enablers. These enablers may help to attain other enablers, those appearing at the middle and top of the ISM based model. Therefore, it is important to focus largely on the cause group enablers at an early stage, so as to measure their impact on the effect group enablers to achieve optimum level of performance.

Enablers having higher driving power are required to be treated on a priority basis, so as there may be few other dependent enablers influenced by them. No enabler was identified as linkage enabler as suggested by MICMAC analysis. Enablers falling in linkage region are unstable, hence require careful managerial attention.

Next, five enablers, 'Resources allocation and information sharing within and across the hierarchy (E6)' 'Joint efforts, planning and capacity building for delivering sustainability focused products (E7); 'Monitoring and auditing the ongoing supply chain activities (E8)'; 'Competitive advantages (E9)' and 'Cost effectiveness and improvements in overall performance (E10)') were identified as dependent enablers on the basis of MICMAC analysis. These enablers should be regarded as important enablers because their strong dependence points out that they need all the other enablers to implement sustainable initiatives. Based on (R-C) dataset, four enablers ('Resources allocation and information sharing within and across the hierarchy (E6)'; 'Joint efforts, planning and capacity building for delivering sustainability focused products (E7); 'Competitive advantages (E9)' and 'Cost effectiveness and improvements in overall performance (E10)') belongs to the effect group, and needs to be focused on to enhance the sustainable development initiatives effectiveness. Anastasiadis and Poole (2015) reported that interorganizational collaboration as well as market strategies and linkages needs to be highly coordinated for sustainable business development in developing economies. Therefore, joint efforts, planning and capacity building for delivering sustainability focused products are required to achieve competitive advantages as well as cost effectiveness and improvements in overall SC performance. Effect group enablers are significantly driven by constructing efforts on the cause group to extract positive outcomes in terms of the effect group enablers. 'Cost effectiveness and 
improvements in overall performance (E10)' obtains the least (R-C) score of -1.77 (receives the highest impact). All cause enablers will enhance cost effectiveness and improvements in overall performance, which reduces the cost of agri-food activities to improve the 'Competitive advantages (E9)' in implementing sustainable initiatives in A-FSCs. Grekova et al. (2015) also suggested that the adoption of sustainable initiatives can direct business organizations towards process improvements and hence achieve high competitive advantages and enhanced performance.

No enabler was identified as an autonomous variable. Therefore, all the enablers influence the implementation of sustainable initiatives in the agri-food sector as suggested by this work.

The results of the combined ISM and fuzzy DEMATEL approach used in this work are very relevant and useful for the managers. The contextual relationships of identified enablers and their hierarchical structuring, using the ISM method, found driving and dependence power in the forms of 'Pressure by various governmental, regulating agencies and non-government bodies (E1)' and 'Understanding customer and other stakeholder requirements (E3)' enablers. These had the lowest dependence power and highest driving power (Table 5). The sustainability oriented supply chains focus has existed due to the demands of government regulations and customer expectations, and the field has matured to the next level of analysis. These enablers are powerful and influential enablers for sustainability adoption in agro supply chains and occupy the bottom position in the structural model. 'Competitive advantages (E9)' and 'Economic cost effectiveness and improvements in overall performance (E10)' enablers found to be the highest dependence power and lowest driving power. These enablers are positioned at top of the hierarchy model.

After discussing the research outcomes with the expert team, the experts seem to have agreement with the findings. However, it is not easy to declare, which enabler in reference to sustainability oriented enable is utmost/least important, so as each enabler has its own significance as a whole. The understanding of both the contextual relationship and the cause and effect relations would be effective in such cases. In this sense, the managers are suggested to evaluate the enablers according to their contextual and causal relations, and put them into practice in a logical way using the hierarchical and cause and effect map. The ISM based hierarchical structure, division of enablers by MICMAC analysis and cause and effect diagram based on fuzzy DEMATEL helps to understand the micro and macro interactions between and among the enablers in 
enhancing the performance of sustainability focused A-FSCs. This may help managers in continuously improving and managing sustainable initiatives in the system. In view of these considerations, we will seek to explore these scenarios in future studies for verification/validation purposes.

\subsection{Implications to the practice/management}

The results presented in this paper have significant managerial/practical implications. The research offers a base to extend the understanding of key enablers to sustainable initiative implementation in A-FSCs. The key enabler concept is very helpful in process improvement in an organizational supply chain context (Rahman and Subramanian, 2012). This further helps in examining the role of people, functions and operations to enhance organization's brand image (Luthra et al., 2018). Thus, developing theory in area of sustainability oriented focused enablers linked to its recognition, need and significance is crucial in integrating sustainability initiative in food value chains. The findings offer supply chain practitioners a more focused approach to segregate important enablers in order to implement sustainable initiatives in the agro-food business and use their scarce improvement resources. Benefits accrue through SSIM for better understanding of interactions of identified enablers in implementing sustainable initiatives. The enablers recognized in this study can serve as a checklist that comprehensively cover possible key factors associated with sustainable development in the agri-food sector. This will also help to seriously examine every enabler and its influence, thus assisting managers to make short-term as well as long-term strategic decisions to meet the requirement of regulatory bodies, customers and other business stakeholders. This work focuses on relevant key enablers, which supported by ISM and MICMAC analysis. A greater understanding of the different enablers and their interdependence in implementing sustainable initiatives has been derived. The enablers with low dependence power and high driving power have more of a tactical orientation, whilst enablers with high dependence power and low driving power have more of a performance orientation. Consequently, better results can be reached by constantly improving the self-governing enablers. The fuzzy DEMATEL based structural decision model helps in uncovering the causal interactions among the various enablers. This can enable managers not only to focus on enablers by considering the causal effect of other enablers, but also suggest means to improve the 
efficiency of successful implementation sustainability initiatives in A-FSCs. In addition to this, the present research work offers also several specific implications for managers and policy makers in food industry, given as below:

Role of government policies and frameworks:

Government plays a very crucial role in defining sustainability objectives in a food value chain within an economy. Governmental support and regulatory framework is significant to deal with issues of infrastructure (e.g. for transport and reliable energy), co-ordination between domestic and international governments. Government supportive polices can assist in open market policy, education programs for farmers, incentives to organizations for assistance in risk management, etc. to promote sustainability practices in food value chains.

\section{Provision of funds and allocation of resources:}

For an organization, it is important to have adequate funds and resources to develop sustainability orientation in its FSC. Management needs to ensure higher funds and superior resources to adopt modern technologies, new machines and equipment's to enhance FSC sustainability. Top management should allocate sufficient resources and funds to invest in research and development activities to promote sustainability.

Development of efficient information technology network:

Information technology network plays a significant role in enhancing the sustainability of food industries. The effective sharing and timely distribution of information can reduce food wastage significantly. Top management should adopt modern information technologies, such as electronic seal, RFID, for food traceability and higher safety and sustainability of food. Food policy managers are also encouraged to apply GPS technique for reducing food wastage and increasing effectiveness.

Training and knowledge development program for stakeholders for behavioral change:

Management should seek to conduct education and training sessions for improving the knowledge and awareness of consumers and farmers. This will assists both the farmers and consumers to change their preferences towards food sustainability. Some of its noticeable benefits could be listed as - reduction in food wastage at both the household and agriculture 
lands, use of improved technologies etc. Periodic workforce training and stakeholder's awareness is also very important to enhancing sustainability implications in food industry.

\section{Conclusions, limitations and future work}

This work contributes contextual relationships and hierarchical levels of key enablers into cause and effect groups to support the implementation sustainable initiatives in A-FSCs. Ten key enablers for implementing sustainable initiatives in the agri-food supply network were documented through literature support and experts' input. The identified enablers were then analyzed using combined ISM - fuzzy DEMATEL based approach.

ISM modeling was applied to recognize the contextual relationships as well as to develop a hierarchical model of identified enablers. 'Pressure by various governments, regulating agencies and non-government bodies (E1)' and 'Understanding customer and other stakeholder requirements (E3)' were identified as bottom level enablers with the highest independence powers. That means that these enablers are influential enablers.

The fuzzy DEMATEL approach uncovered the influenced and influential interactions (causal interactions) among the identified enablers. Based on this, six enablers (Pressure by various governmental, regulating agencies and non-government bodies (E1), Incentives and support of various agencies to undertake sustainable initiatives (E2), Understanding customer and other stakeholder requirements (E3), Understanding the sustainability initiative importance and benefits (E4), Management involvement, support and commitment (E5) and Monitoring and auditing the ongoing supply chain activities (E8)) were categorized in the cause group and the remaining four (Resources allocation and information sharing within and across the hierarchy (E6), Joint efforts, planning and capacity building for delivering sustainability focused products (E7), Competitive advantages (E9) and Cost effectiveness and improvements in overall performance (E10)) in the effect group. The cause-effect diagram assists in analyzing the interactions among the enablers in enhancing the implementation of sustainability focused concepts in the agro-food business.

The proposed framework can be engaged to evaluate and answer the question of what needs to be done to achieve long-term business success. Practically this adds significant management value to the case company and its highly complex value chain. 
The limitations of this research concern the subjective cause-effect diagram build on the judgments of experts from a particular industry. Further, the identification of the enablers could be challenging. In case of developing country like India, some enablers have utmost influential capabilities may become less important in future, and some enabler may become more important once food industries matured in sustainability. Next, because of superior technological and process innovations, the food sector may be transformed in near future, so as the extension of fuzzy theory with ISM-MICAMC can be explored. In the future research, an attempt may be made for evaluating the interpretive logic of all the interactions towards interpreting the structural model completely. Further, model verification and validation are targeted as a potential investigational area by the authors for the future. The proposed ISM based hierarchical model may be verified by using Structural Equation Modeling (SEM) in future. The identified enablers to implement sustainable initiatives in A-FSC may be quantified in order to obtain appropriate results by using other decision-making techniques. It is also believed that this work lays the foundation for broadening research in area of sustainability in Agro food value chains.

\section{References}

Accorsi, R., Cholette, S., Manzini, R., Pini, C., Penazzi, S., 2016. The land-network problem: ecosystem carbon balance in planning sustainable agro-food supply chains. Journal of Cleaner Production, 112, 158-171.

Ageron, B., Gunasekaran, A., Spalanzani, A., 2012. Sustainable supply management: an empirical study. International Journal of Production Economics, 140 (1), 168-182.

Ahumada, O., Villalobos, J.R., 2009. Application of planning models in the agri-food supply chain: a review. European Journal of Operational Research, 196 (1), 1-20.

Akhtar, P., Tse, Y. K., Khan, Z., Rao-Nicholson, R., 2016. Data-driven and adaptive leadership contributing to sustainability: global agri-food supply chains connected with emerging markets. International Journal of Production Economics, 181, 392-401.

Al Zaabi, S., Al Dhaheri, N., Diabat, A. 2013. Analysis of interaction between the barriers for the implementation of sustainable supply chain management. International Journal of Advanced Manufacturing Technology, 68(14), 895-905.

Anastasiadis, F., Poole, N., 2015. Emergent supply chains in the agrifood sector: insights from a whole chain approach. Supply Chain Management: An International Journal, 20(4), 353-368.

Anupam, S. (2017). Key takeaways for the agri-food industry from Inc42 and Mistletoe's farm to fork conclave. Online available at: https://inc42.com/buzz/farm-to-fork-agrifood-mistletoe/ (last accessed: April 7, 2018).

Balaji, M., Arshinder, K., 2016. Modeling the causes of food wastage in Indian perishable food supply chain. Resources, Conservation and Recycling, 114, 153-167. 
Banasik, A., Kanellopoulos, A., Claassen, G.D.H., Bloemhof-Ruwaard, J.M., van der Vorst, J.G., 2017. Closing loops in agricultural supply chains using multi-objective optimization: a case study of an industrial mushroom supply chain. International Journal of Production Economics, 183, 409-420.

Beske, P., Land, A., Seuring, S., 2014. Sustainable supply chain management practices and dynamic capabilities in the food industry: a critical analysis of the literature. International Journal of Production Economics, 152, 131143.

Beske, P., Seuring, S., 2014. Putting sustainability into supply chain management. Supply Chain Management: An International Journal, 19 (3), 322-331.

Bhaskaran, S., Polonsky, M., Cary, J., Fernandez, S., 2006. Environmentally sustainable food production and marketing: opportunity or hype?. British Food Journal, 108 (8), 677-690.

Birthal, P. S., Negi, D. S., Khan, M. T., Agarwal, S., 2015. Is Indian agriculture becoming resilient to droughts? evidence from rice production systems. Food Policy, 56, 1-12.

Bitzer, V., Francken, M., Glasbergen, P., 2008. Inter-sectoral partnerships for a sustainable coffee chain: really addressing sustainability or just picking (coffee) cherries? Global Environmental Change, 18 (2), 271-284.

Bloom, J.D., 2015. Standards for development: food safety and sustainability in Wal-Mart's Honduran produce supply chains. Rural Sociology, 80 (2), 198-227.

Bourlakis, M.A. and Weightman, P.W. eds., 2008. Food Supply Chain Management. John Wiley \& Sons, United States.

Bowen, F.E., Cousins, P.D., Lamming, R.C., Faruk, A.C., 2001. Horses for courses. Greener Management International, 35(1), 41-60.

Business Dictionary, 2016. Enablers. Accessed from http://www.businessdictionary.com/definition/ enablers on 6th January 2017.

Cagliano, R., Worley, C.G., \& Caniato, F.F. 2016. The Challenge of Sustainable Innovation in Agri-Food Supply Chains. In Organizing Supply Chain Processes for Sustainable Innovation in the Agri-Food Industry (pp. 1-30). Emerald Group Publishing Limited.

Chen K., 2006. Agri-Food Supply Chain Management: opportunities, Issues, and Guidelines. International Conference on Livestock Services, April 16-22, Beijing, People's Republic of China.

Chkanikova, O., Lehner, M., 2015. Private eco-brands and green market development: Towards new forms of sustainability governance in the food retailing. Journal of Cleaner Production, 107, 74-84.

Chuang, H.M., Lin, C.K., Chen, D.R., \& Chen, Y.S., 2013. Evolving MCDM applications using hybrid expertbased ISM and DEMATEL models: an example of sustainable ecotourism. The Scientific World Journal, 1-18.

Clemens, B., Douglas, T.J., 2006. Does coercion drive firms to adopt 'voluntary' green initiatives? Relationships among coercion, superior firm resources, and voluntary green initiatives. Journal of Business Research, 59 (4), 483-491.

Clement, S.K., Pun, K.F., Motilal, C.B. 2006. Adopting a national innovation approach for agro-sustainability: a case study. Asian Journal on Quality, 7 (3), 98-106. 
Closs, D.J., Speier, C., Meacham, N., 2011. Sustainability to support end-to-end value chains: the role of supply chain management. Journal of the Academy of Marketing Science, 39 (1), 101-116.

Darbari, J.D., Agarwal, V., Sharma, R., Jha, P.C., 2018. Analysis of impediments to sustainability in the food supply chain: an interpretive structural modeling approach. In Quality, IT and Business Operations (pp. 57-68). Springer, Singapore.

Dev, S.M., Mishra, S., Pandey, V.L. 2014. Agriculture in India: Performance, Challenges and Opportunities. The Oxford Handbook of the Indian Economy in the 21st Century, Oxford University Press, New Delhi, 641-665.

Diabat, A., Govindan, K., 2011. An analysis of the drivers affecting the implementation of green supply chain management. Resources, Conservation and Recycling, 55 (6), 659-667.

Ding, H., Fu, Y., Zheng, L., Yan, Z., 2018. Determinants of the competitive advantage of dairy supply chains: evidence from the Chinese dairy industry. International Journal of Production Economics, https://doi.org/10.1016/j.ijpe.2018.02.013

Djekic, I., Dragojlovic, S., Miloradovic, Z., Miljkovic-Zivanovic, S., Savic, M., Kekic, V., 2016. Improving the confectionery industry supply chain through second party audits. British Food Journal, 118 (5), 1041-1066.

dos Muchangos, L.S., Tokai, A., Hanashima, A., 2015. Analyzing the structure of barriers to municipal solid waste management policy planning in Maputo city, Mozambique. Environmental Development, 16, 76-89.

Eisenhardt, K. M., 1989. Building theories from case study research. Academy of Management Review, 14(4), 532550 .

Elkington, J., 1994. Towards the sustainable corporation: win-win-win business strategies for sustainable development. California Management Review, 36 (2), 90-100.

Ellis, N., Higgins, M., 2006. Recatechizing codes of practice in supply chain relationships: discourse, identity and otherness. Journal of Strategic Marketing, 14(4), 387-410.

FACCE-JPI, 2011. Scientific research agenda of the 'agriculture, food security and climate change. Joint Programming Research Initiative.

FAO 2006. World reference base for soil resources - a framework for international classification, correlation and communication. World Soil Resources Report, Food and Agriculture Organization of the United Nations 103.

FAO 2009. The state of fisheries and aquaculture 2008. Food and Agriculture Organization of the United Nations, Rome, Italy, 1-196.

Fischer, C., Hartmann, M., Reynolds, N., Leat, P., Revoredo-Giha, C., Henchion, M., ... Gracia, A., 2010. Factors influencing contractual choice and sustainable relationships in European agri-food supply chains. European Review of Agricultural Economics, doi: 10.1093/erae/jbp041

Florida, R., 1996. Lean and green: the move to environmentally conscious manufacturing. California Management Review, 39(1), 80-105.

Fontela, E., Gabus, A., 1976. Current perceptions of the world problematique. World Modeling: A Dialogue. North-Holland Publishing Company, Amsterdam/Oxford.

Food Ethics Council., 2004. Just knowledge? Governing research on food and farming. Brighton: Food Ethics Council. 
Fritz, M., Schiefer, G., 2008. Food chain management for sustainable food system development: a European research agenda. Agribusiness, 24(4), 440-452.

Gandhi, S., Mangla, S. K., Kumar, P., Kumar, D., 2015. Evaluating factors in implementation of successful green supply chain management using DEMATEL: a case study. International Strategic Management Review, 3 (1), 96-109.

Gimenez, C., Sierra, V., 2013. Sustainable supply chains: Governance mechanisms to greening suppliers. Journal of Business Ethics, 116(1), 189-203.

Glover, J.L., Champion, D., Daniels, K.J., Dainty, A.J.D., 2014. An institutional theory perspective on sustainable practices across the dairy supply chain. International Journal of Production Economics, 152, 102-111.

Govindan, K., 2018. Sustainable consumption and production in the food supply chain: a conceptual framework. International Journal of Production Economics, 195, 419-431.

Grant Thornton., 2014. Indian food \& beverage sector the new wave. Confederation of Indian Industries, 16-38. Online available at: http://www.grantthornton.in/insights/articles/indian-food--beverage-sector-the-new-wave/ (Last accessed: January 18, 2018).

Grekova, K., Calantone, R.J., Bremmers, H.J., Trienekens, J.H., Omta, S.W.F., 2015. How environmental collaboration with suppliers and customers influences firm performance: evidence from Dutch food and beverage processors. Journal of Cleaner Production, 30, 1-11.

Grimm, J. H., Hofstetter, J. S., Sarkis, J., 2014. Critical factors for sub-supplier management: a sustainable food supply chains perspective. International Journal of Production Economics, 152, 159-173.

Grunfeld, H., Houghton, J., 2013. Using ICT for climate change adaptation and mitigation through agro-ecology in the developing world. Proceedings of First International Conference on Information and Communication Technologies, Paper ID: 128.

Gustavsson, J., Cederberg, C., Sonesson, U., Van Otterdijk, R., Meybeck, A., 2015. Global food losses and food waste. Food and Agriculture Organziation of the United Nations Website, pp. 1-37.

Hartono, Y., Astanti, R.D., Ai, T.J., 2015. Enabler to successful implementation of lean supply chain in a book publisher. Procedia Manufacturing, 4, 192-199.

Holt, D., Ghobadian, A., 2009. An empirical study of green supply chain management practices amongst UK manufacturers. Journal of Manufacturing Technology Management, 20 (7), 933-956.

Hong, P., Kwon, H.B., Jungbae Roh, J., 2009. Implementation of strategic green orientation in supply chain: an empirical study of manufacturing firms. European Journal of Innovation Management, 12 (4), 512-532.

Hsu, C.W., Kuo, T.C., Chen, S.H., Hu, A.H., 2013. Using DEMATEL to develop a carbon management model of supplier selection in green supply chain management. Journal of Cleaner Production, 56, 164-172.

Humphrey, J., Memedovic, O., 2006. Global value chains in the agri food sector. Institute of Development Studies, University of Sussex, Brighton, United Kingdom.

Iakovou, E., Vlachos, D., Achillas, C., Anastasiadis, F., 2014. Design of sustainable supply chains for the agrifood sector: a holistic research framework. Agricultural Engineering International: CIGR Journal, 1 (1) 1-10. 
Ilbery, B., Maye, D., Kneafsey, M., Jenkins, T., Walkley, C., 2004. Forecasting food supply chain developments in lagging rural regions: evidence from the UK. Journal of Rural Studies, 20 (3), 331-344.

Jaffee, D., Howard, P.H., 2010. Corporate cooptation of organic and fair trade standards. Agriculture and Human Values, 27 (4), 387-399.

Jakhar, S. K., Barua, M. K. 2014. An integrated model of supply chain performance evaluation and decisionmaking using structural equation modelling and fuzzy AHP. Production Planning \& Control, 25 (11), 938-957.

Klassen, R.D., Vachon, S., 2003. Collaboration and evaluation in the supply chain: the impact on plant-level environmental investment. Production and Operations Management, 12 (3), 336-352.

Kumar, D., Rahman, Z. Chan, F.T.S. (2016) A Fuzzy AHP and Fuzzy multi-objective linear programming model for order allocation in a sustainable supply chain: a case study. International Journal of Computer Integrated Manufacturing, http://dx.doi.org/10.1080/0951192X.2016.1145813

Kumar, D., Rahman, Z., 2013. Modelling relationship marketing strategies for sustainability adoption. International Journal of Intercultural Information Management, 3 (4), 277-291.

Kumar, D., Rahman, Z., 2015. Sustainability adoption through buyer supplier relationship across supply chain: a literature review and conceptual framework. International Strategic Management Review, 3 (1), 110-127.

Kumar, R., Agrawal, R., Sharma, V., 2013. E-applications in Indian agri-food supply chain: relationship among enablers. Global Business Review, 14 (4), 711-727.

Kumari, L., Narsaiah, K., Grewal, M.K., Anurag, R.K., 2015. Application of RFID in agri-food sector. Trends in Food Science \& Technology, 43 (2), 144-161.

Lee, S.Y., 2008. Drivers for the participation of small and medium-sized suppliers in green supply chain initiatives. Supply Chain Management: An International Journal, 13 (3), 185-198.

Li, D., Wang, X., Chan, H.K., Manzini, R., 2014. Sustainable food supply chain management. International Journal of Production Economics, 152(0), 1-8.

Lin, C.Y., 2007. Adoption of green supply chain practices in Taiwan's logistics industry. Journal of International Management Studies, 2 (2), 90-98.

Lin, R.J., 2013. Using fuzzy DEMATEL to evaluate the green supply chain management practices. Journal of Cleaner Production, 40, 32-39.

Lowe, P., Phillipson, J., Lee, R. P., 2008. Socio-technical innovation for sustainable food chains: roles for social science. Trends in Food Science \& Technology, 19 (5), 226-233.

Lundqvist, J., de Fraiture, C., Molden, D., 2008. Saving water: from field to fork: curbing losses and wastage in the food chain. Stockholm, Sweden: Stockholm International Water Institute (SIWI), pp.1-35.

Luthra, S., Garg, D., Haleem, A., 2015. An analysis of interactions among critical success factors to implement green supply chain management towards sustainability: An Indian perspective. Resources Policy, 46, 37-50.

Luthra, S., Govindan, K., Kharb, R. K., Mangla, S. K., 2016a. Evaluating the enablers in solar power developments in the current scenario using fuzzy DEMATEL: An Indian perspective. Renewable and Sustainable Energy Reviews, 63, 379-397.

Luthra, S., Mangla, S. K., Xu, L., Diabat, A., 2016b. Using AHP to evaluate barriers in adopting sustainable 
consumption and production initiatives in a supply chain. International Journal of Production Economics, 181, 342-349.

Luthra, S., Govindan, K., Kannan, D., Mangla, S. K., Garg, C. P., 2017. An integrated framework for sustainable supplier selection and evaluation in supply chains. Journal of Cleaner Production, 140, 1686-1698.

Luthra, S., Mangla, S.K., Shankar, R., Garg, C.P., Jakhar, S. 2018. Modelling critical success factors for sustainability initiatives in supply chains in Indian context using Grey-DEMATEL. Production Planning \& Control, 1-24.

Mandal, A., Deshmukh, S.G., 1994. Vendor selection using interpretive structural modelling (ISM). International Journal of Operations \& Production Management, 14 (6), 52-59.

Mangla, S. K., Govindan, K., Luthra, S. 2016. Critical success factors for reverse logistics in Indian industries: a structural model. Journal of Cleaner Production, 129, 608-621.

Mangla, S. K., Kumar, P., Barua, M. K. 2015. Flexible decision modeling for evaluating the risks in green supply chain using fuzzy AHP and IRP methodologies. Global Journal of Flexible Systems Management, 16 (1), 1935.

Mangla, S., Madaan, J., Chan F.T.S., 2013. Analysis of flexible decision strategies for sustainability-focused green product recovery system. International Journal of Production Research, 51 (11), 3443-346.

Mangla, S., Madaan, J., Chan, F.T., 2012. Analysis of performance focused variables for multi-objective flexible decision modeling approach of product recovery systems. Global Journal of Flexible Systems Management, 13 (2), 77-86.

Mangla, S., Madaan, J., Sarma, P.R.S., Gupta, M.P., 2014. Multi-objective decision modelling using interpretive structural modelling for green supply chains. International Journal of Logistics Systems and Management, 17 (2), 125-142.

Mani, V., Gunasekaran, A., 2018. Four forces of supply chain social sustainability adoption in emerging economies. International Journal of Production Economics, 199, 150-161.

Markley, M.J., Davis, L., 2007. Exploring future competitive advantage through sustainable supply chains. International Journal of Physical Distribution \& Logistics Management, 37 (9), 763-774.

Mathiyazhagan, K., Govindan, K., NoorulHaq, A., Geng, Y., 2013. An ISM approach for the barrier analysis in implementing green supply chain management. Journal of Cleaner Production, 47, 283-297.

Matos, S., Hall, J., 2007. Integrating sustainable development in the supply chain: the case of life cycle assessment in oil and gas and agricultural biotechnology. Journal of Operations Management, 25 (6), 1083-1102.

Mehregan, M. R., Hashemi, S. H., Karimi, A., \& Merikhi, B. (2014). Analysis of interactions among sustainability supplier selection criteria using ISM and fuzzy DEMATEL. International Journal of Applied Decision Sciences, 7(3), 270-294.

Mohezar, S., Soosay, C., 2010. A structural analysis of information technology (IT) integration in food supply chains and firm. Innovative Process Optimization Methods in Logistics: Emerging Trends, Concepts and Technologies, 13, 17. 
Nakano, K., Hirao, M., 2011. Collaborative activity with business partners for improvement of product environmental performance using LCA. Journal of Cleaner Production, 19 (11), 1189-1197.

Notarnicola, B., Hayashi, K., Curran, M.A., Huisingh, D., 2012. Progress in working towards a more sustainable agri-food industry. Journal of Cleaner Production, 28, 1-8.

Patil, S.K., Kant, R., 2014. A hybrid approach based on fuzzy DEMATEL and FMCDM to predict success of knowledge management adoption in supply chain. Applied Soft Computing, 18, 126-135.

Peters, N.J., Hofstetter, J.S., Hoffmann, V.H., 2011. Institutional entrepreneurship capabilities for interorganizational sustainable supply chain strategies. The International Journal of Logistics Management, 22 (1), 52-86.

Pugliese, P., 2001. Organic farming and sustainable rural development: A multifaceted and promising convergence. Sociologia Ruralis, 41 (1), 112-130.

Rahman, S., Subramanian, N., 2012. Factors for implementing end-of-life computer recycling operations in reverse supply chains. International Journal of Production Economics, 140(1), 239-248.

Raj, T., Shankar, R., Suhaib, M. 2010. GTA-based framework for evaluating the feasibility of transition to FMS. Journal of Manufacturing Technology Management, 21(2), 160-187.

Rao, P., Holt, D., 2005. Do green supply chains lead to competitiveness and economic performance? International Journal of Operations \& Production Management, 25 (9), 898-916.

Raut, R.D., Narkhede, B., Gardas, B.B., 2017. To identify the critical success factors of sustainable supply chain management practices in the context of oil and gas industries: ISM approach. Renewable and Sustainable Energy Reviews, 68, 33-47.

Ravi, V., Shankar, R., 2005. Analysis of interactions among the barriers of reverse logistics. Technological Forecasting and Social Change, 72(8), 1011-1029.

Sakschewski, B., von Bloh, W., Huber, V., Müller, C., Bondeau, A., 2014. Feeding 10 billion people under climate change: how large is the production gap of current agricultural systems? Ecological Modelling, 288, 103-111.

Seuring, S., Müller, M., 2008. From a literature review to a conceptual framework for sustainable supply chain management. Journal of Cleaner Production, 16 (15), 1699-1710.

Sgarbossa, F., Russo, I., 2017. A proactive model in sustainable food supply chain: insight from a case study. International Journal of Production Economics, 183, 596-606.

Sharma, V.P., 2011. India's agricultural development under the new economic regime: Policy perspective and strategy for the 12th five-year plan. Indian Institute of Management, W.P. No. 2011-11-01

Simpson, D.F., Power, D.J., 2005. Use the supply relationship to develop lean and green suppliers. Supply Chain Management: An international Journal, 10 (1), 60-68.

Singh, M., Sachdeva, A., Bhardwaj, A., 2014. An interpretive structural modelling approach foanalysing barriers in total productive maintenance implementation. International Journal of Industrial and Systems Engineering, 16 (4), 433-450.

Somashekhar, I.C., Raju, J.K., Patil, H., 2014. Agriculture supply chain management: A scenario in India. Research Journal of Social Science and Management, 4(7), 89-99. 
Stevens, T.M., Aarts, N., Termeer, C.J.A.M., Dewulf, A., 2016. Social media as a new playing field for the governance of agro-food sustainability. Current Opinion in Environmental Sustainability, 18, 99-106.

Svensson, G., Wagner, B., 2012. Implementation of a sustainable business cycle: The case of a Swedish dairy producer. Supply Chain Management: An International Journal, 17 (1), 93-97.

Syahruddin, N., Kalchschmidt, M., 2012. Sustainable supply chain management in the agricultural sector: a literature review. International Journal of Engineering Management and Economics, 3 (3), 237-258.

Talib, F., Rahman, Z., Qureshi, M.N., 2011. Analysis of interaction among the barriers to total quality management implementation using interpretive structural modeling approach. Benchmarking: An International Journal, 18 (4), 563-587.

Teuteberg, F., Wittstruck, D., 2010. A systematic review of sustainable supply chain management. Multikonferenz Wirtschaftsinformatik, 203-204.

Ting, S. L., Tse, Y. K., Ho, G. T. S., Chung, S. H., Pang, G., 2014. Mining logistics data to assure the quality in a sustainable food supply chain: a case in the red wine industry. International Journal of Production Economics, 152, 200-209.

Vachon, S., Klassen, R. D., 2008. Environmental management and manufacturing performance: the role of collaboration in the supply chain. International Journal of Production Economics, 111 (2), 299-315.

Van Bommel, H.W., 2011. A conceptual framework for analyzing sustainability strategies in industrial supply networks from an innovation perspective. Journal of Cleaner Production, 19 (8), 895-904.

Vermeulen, W.J., Ras, P.J., 2006. The challenge of greening global product chains: meeting both ends. Sustainable Development, 14 (4), 245-256.

Wagner, S. M., Neshat, N. 2010. Assessing the vulnerability of supply chains using graph theory. International Journal of Production Economics, 126 (1), 121-129.

Walker, H., Di Sisto, L., McBain, D., 2008. Drivers and barriers to environmental supply chain management practices: lessons from the public and private sectors. Journal of Purchasing and Supply Management, 14 (1), 69-85.

Warfield, J. N., 1974. Developing interconnection matrices in structural modeling. Systems, Man and Cybernetics, IEEE Transactions on, 1 (1), 81-87.

WCED, U., 1987. Our common future. World Commission on Environment and Development. Oxford University Press, U.S.A.

Wittstruck, D., Teuteberg, F., 2012. Understanding the success factors of sustainable supply chain management: empirical evidence from the electrics and electronics industry. Corporate Social Responsibility and Environmental Management, 19 (3), 141-158.

Wu, W.W., 2012. Segmenting critical factors for successful knowledge management implementation using the fuzzy DEMATEL method. Applied Soft Computing, 12 (1), 527-535.

Wu, Z., Pagell, M., 2011. Balancing priorities: Decision-making in sustainable supply chain management. Journal of Operations Management, 29 (6), 577-590. 
Yakovleva, N., Sarkis, J., Sloan, T., 2012. Sustainable benchmarking of supply chains: the case of the food industry. International Journal of Production Research, 50 (5), 1297-1317.

Zanoni, S., Zavanella, L., 2012. Chilled or frozen? Decision strategies for sustainable food supply chains. International Journal of Production Economics, 140(2), 731-736.

Zhu, Q., Sarkis, J., 2004. Relationships between operational practices and performance among early adopters of green supply chain management practices in Chinese manufacturing enterprises. Journal of Operations Management, 22 (3), 265-289.

Zhu, Q., Sarkis, J., Lai, K.H., 2008. Confirmation of a measurement model for green supply chain management practices implementation. International Journal of Production Economics, 111 (2), 261-273.

Zsidisin, G.A., Hendrick, T.E., 1998. Purchasing's involvement in environmental issues: a multi-country perspective. Industrial Management \& Data Systems, 98 (7), 313-320. 


\section{Appendix A}

\section{Description for Steps of fuzzy DEMATEL}

Construct a fuzzy pair wise comparison matrix. The pair-wise comparisons are made to develop the initial direct relation matrix using a 0-4 scale (from $0=$ no influence to $4=$ very high influence) according to the opinions of a panel of experts. Considering this, experts are asked to make their linguistic judgment to develop a relation matrix of the evaluation criteria. To capture the fuzziness in the judgments, positive triangular fuzzy numbers (TFN) and a fuzzy linguistic scale are used.

Develop the fuzzy average direct relation matrix (A). The TFN is denoted by a triplet, i.e. $\left(e_{i j}, f_{i j}, g_{i j}\right)$. Suppose $x_{i j}^{k}=e_{i j}^{k}, f_{i j}^{k}, g_{i j}^{k}$ where $1 \leq k \leq K$, is the fuzzy evaluation that the $k^{\text {th }}$ expert in the decision panel gives about the degree to which criteria $\mathrm{i}$ has impact on criteria $\mathrm{j}$. If there are ' $\mathrm{K}$ ' experts in a panel to estimate causality between the identified key enablers

and given by $x_{i j}^{k}$, then the inputs given by a panel of experts have to result in an $n \times n$ matrix i.e. $X^{k}=\mathrm{x}_{\mathrm{ij}}^{\mathrm{k}}$; where, $\mathrm{k}=1,2,3,4 \ldots \mathrm{k}$ (number of experts in a decision panel).

Develop a cause and effect graph. This is plotted using the dataset $(\mathrm{R}+\mathrm{C} ; \mathrm{R}-\mathrm{C})$. The dataset $(\mathrm{R}+\mathrm{C})$ is known as 'Prominence' not only illustrates the significance of enablers to implement sustainable initiatives in the agri-food supply chain, but also shows the total effect in terms of influenced and influential power for the enablers. In addition, the (R-C) i.e. 'Relation or influence' represents the entire effect of enablers to implement sustainable initiatives in the agri-food supply chain. Further based on the value of the dataset (R-C), we can classify the enablers into cause (if (R-C) is positive) and effect group (if (R-C) is negative). 


\section{Appendix B}

Table B.1: Initial reachability matrix for enablers to implement sustainable initiatives in A-FSC

\begin{tabular}{c|l|l|l|l|l|l|l|l|l|l}
\hline Enablers & $\mathbf{1}$ & $\mathbf{2}$ & $\mathbf{3}$ & $\mathbf{4}$ & $\mathbf{5}$ & $\mathbf{6}$ & $\mathbf{7}$ & $\mathbf{8}$ & $\mathbf{9}$ & $\mathbf{1 0}$ \\
\hline E1 & 1 & 1 & 1 & 1 & 1 & 1 & 1 & 1 & 0 & 1 \\
\hline E2 & 0 & 1 & 0 & 1 & 1 & 0 & 0 & 0 & 1 & 1 \\
\hline E3 & 1 & 1 & 1 & 1 & 1 & 0 & 0 & 1 & 1 & 1 \\
\hline E4 & 0 & 1 & 0 & 1 & 1 & 1 & 1 & 1 & 1 & 1 \\
\hline E5 & 0 & 0 & 0 & 0 & 1 & 1 & 1 & 1 & 1 & 1 \\
\hline E6 & 0 & 0 & 0 & 0 & 0 & 1 & 1 & 0 & 0 & 0 \\
\hline E7 & 0 & 0 & 0 & 0 & 0 & 1 & 1 & 0 & 1 & 1 \\
\hline E8 & 0 & 0 & 0 & 0 & 0 & 1 & 1 & 1 & 1 & 1 \\
\hline E9 & 0 & 0 & 0 & 0 & 0 & 0 & 0 & 0 & 1 & 1 \\
\hline E10 & 0 & 0 & 0 & 0 & 0 & 0 & 0 & 0 & 1 & 1 \\
\hline
\end{tabular}

Table B.2: Iteration I for enablers to implement sustainable initiatives in A-FSC

\begin{tabular}{c|l|l|l|c}
\hline Enablers & Reachability Set & Antecedents Set & Intersection Set & Level \\
\hline E1 & $1,2,3,4,5,6,7,8,9,10$ & 1,3 & 1,3 & \\
\hline E2 & $2,4,5,6,7,8,9,10$ & $1,2,3,4$ & 2,4 & \\
\hline E3 & $1,2,3,4,5,6,7,8,9,10$ & 1,3 & 1,3 & \\
\hline E4 & $2,4,5,6,7,8,9,10$ & $1,2,3,4$ & 2,4 & \\
\hline E5 & $5,6,7,8,9,10$ & $1,2,3,4,5$ & 5 & \\
\hline E6 & $6,7,9,10$ & $1,2,3,4,5,6,7,8$ & 6,7 & \\
\hline E8 & $6,7,9,10$ & $1,2,3,4,5,6,7,8$ & 6,7 & \\
\hline E9 & $6,7,8,9,10$ & $1,2,3,4,5,8$ & 8 & $\mathbf{1}$ \\
\hline E10 & 9,10 & $1,2,3,4,5,6,7,8,9,10$ & 9,10 & $\mathbf{1}$ \\
\hline
\end{tabular}




\section{Appendix - C}

Table C.1: The fuzzy assessment provided data by the expert panel

\begin{tabular}{c|c|c|c|c|c|c|c|c|c|c}
\hline Enablers & $\mathbf{1}$ & $\mathbf{2}$ & $\mathbf{3}$ & $\mathbf{4}$ & $\mathbf{5}$ & $\mathbf{6}$ & $\mathbf{7}$ & $\mathbf{8}$ & $\mathbf{9}$ & $\mathbf{1 0}$ \\
\hline E1 & No & H & H & H & H & H & VH & H & VH & VH \\
\hline E2 & L & No & H & H & L & H & VH & VH & H & VH \\
\hline E3 & H & H & No & VH & H & H & H & H & VH & VH \\
\hline E4 & H & H & H & No & L & H & H & VH & VH & H \\
\hline E5 & L & H & L & H & No & H & H & VH & H & H \\
\hline E6 & L & L & L & L & H & No & H & L & L & H \\
\hline E7 & L & L & L & L & H & L & No & L & H & H \\
\hline E8 & L & L & L & H & H & H & H & No & VH & VH \\
\hline E9 & H & L & L & VL & L & H & H & VL & No & VL \\
\hline E10 & L & L & L & L & L & H & L & VL & VL & No \\
\hline
\end{tabular}

Table C.2: Fuzzy normalized direct relation matrix for enablers to implement sustainable initiatives in A-FSC

\begin{tabular}{c|c|c|c|c|c|c|c|c|c|c}
\hline Enablers & $\mathbf{1}$ & $\mathbf{2}$ & $\mathbf{3}$ & $\mathbf{4}$ & $\mathbf{5}$ & $\mathbf{6}$ & $\mathbf{7}$ & $\mathbf{8}$ & $\mathbf{9}$ & $\mathbf{1 0}$ \\
\hline E1 & 0.01 & 0.10 & 0.10 & 0.10 & 0.10 & 0.10 & 0.13 & 0.10 & 0.13 & 0.13 \\
\hline E2 & 0.07 & 0.01 & 0.10 & 0.10 & 0.07 & 0.10 & 0.13 & 0.13 & 0.10 & 0.13 \\
\hline E3 & 0.10 & 0.10 & 0.01 & 0.13 & 0.10 & 0.10 & 0.10 & 0.10 & 0.13 & 0.13 \\
\hline E4 & 0.10 & 0.10 & 0.10 & 0.01 & 0.07 & 0.10 & 0.10 & 0.13 & 0.13 & 0.10 \\
\hline E5 & 0.07 & 0.10 & 0.07 & 0.10 & 0.01 & 0.10 & 0.10 & 0.13 & 0.10 & 0.10 \\
\hline E6 & 0.07 & 0.07 & 0.07 & 0.07 & 0.10 & 0.01 & 0.10 & 0.07 & 0.07 & 0.10 \\
\hline E7 & 0.07 & 0.07 & 0.07 & 0.07 & 0.10 & 0.07 & 0.01 & 0.07 & 0.10 & 0.10 \\
\hline E8 & 0.07 & 0.07 & 0.07 & 0.10 & 0.10 & 0.10 & 0.10 & 0.01 & 0.13 & 0.13 \\
\hline E9 & 0.10 & 0.07 & 0.07 & 0.03 & 0.07 & 0.10 & 0.07 & 0.03 & 0.01 & 0.03 \\
\hline E10 & 0.07 & 0.07 & 0.07 & 0.07 & 0.07 & 0.10 & 0.07 & 0.03 & 0.03 & 0.01 \\
\hline
\end{tabular}

